\title{
El deslinde de las Vías Pecuarias y su control judicial
}

\author{
Eloísa Mํㅡㄹez Andrés \\ Abogada. Profesora Asociada \\ de la Universidad Pablo de Olavide
}

\begin{abstract}
SUMARIO: INTRODUCGIÓN: I. ESPECIAL CONFIGURACIÓN DEL DESLINDE DE VÍAS PECUARIAS. II. LA CLASIFICACIÓN DE LAS VÍAS PECUARIAS Y SU RELACIÓN CON EL DESLINDE. a) Función, contenido y clasificación. b) Efecto meramente declarativo de la clasificación de vías pecuarias: importancia esencial de la fase previa de investigación. c) Relación clasificación-deslinde. III. EL DESLINDE DE VÍAS PECUARIAS. a) Concepto y naturaleza del deslinde de vías pecuarias en su perspectiva histórica. b) Concepto y efectos del deslinde en la Ley 3/1995. c) Procedimiento de deslinde de vías pecuarias: especial referencia al problema de su caducidad, IV. EL CONTROL JUDICIAL DEL DESLINDE DE VÍAS PECUARIAS. a) Competencia del Orden Jurisdiccional Civil. b) Impugnación ante la jurisdicción Contencioso-Administrativa.. i. Impugnación de la Clasificación. ii. Impugnación del acto de deslinde.
\end{abstract}

El tema objeto de este estudio es el análisis del polémico deslinde de vías pecuarias y, digo polémico porque tanto a nivel doctrinal, como en la realidad práctica de nuestra Comunidad Autónoma y general de toda España está siendo foco de no pocos contenciosos, y los que aún están por venir. Ciertamente desde que en 1995 la Ley del Estado atribuyó la titularidad dominical de las vías pecuarias a las CCAA, todas ellas y, para nosotros especialmente Andalucía, han puesto en marcha una campaña de tramitación de expedientes de deslindes que se eternizan en el tiempo creando una grave situación de inseguridad jurídica e incertidumbre -a la que solo la institución de la caducidad puede dar certeza y seguridad-, y que, como un meteorito irrumpen en medio de explotaciones agrícolas, cinegéticas, campos de golf, incluso tejidos urbanos... configurados y consolidados con el paso de los años de desuso de las vías pecuarias. 
El deslinde de las vías pecuarias, como vamos a ver es un tema en ebullición, un tema candente, no solo por el atrevimiento de la Ley en la regulación de sus efectos, sino por la intensa e irregular aplicación que se esta haciendo en los últimos años de esta manifestación de la potestad de autotutela de los bienes de dominio publico en nuestra Comunidad Autónoma.

\section{INTRODUCGIÓN: ESPECIAL CONFIGURACIÓN DEL DESLINDE DE VIAS PECUARIAS}

Tradicionalmente el deslinde se ha configurado como una potestad de autotutela de los bienes de dominio público que consiste en fijar con certeza los límites de estos bienes en relación a los colindantes, declarando la posesión de los mismos por la Administración Pública. Se trata de una potestad cuyo ejercicio está legitimado, como explica el Profesor CARRILLO DONAIRE ${ }^{1}$ cuando los límites de los bienes no sean precisos y existan indicios de usurpación. Los efectos pues del deslinde se mueven tradicionalmente en el ámbito posesorio, de forma que el deslinde no prevalece sobre las inscripciones registrales sino que ha de respetar los derechos inscritos en el Registro de la Propiedad que gozan de la presunción de legalidad establecida en el art. 38 de la LH y que están, conforme al art. 1 de la LH, bajo la salvaguardia de los tribunales.

Frente a esta concepción tradicional del deslinde de los bienes de dominio público, el art. 8 de la Ley 3/1995 define el deslinde de vías pecuarias y sus efectos en los siguientes términos:

"1. El deslinde es el acto administrativo por el que se definen los limites de las vías pecuarias conforme a lo establecido en el acto de clasificación"

“3. El deslinde aprobado declara la posesión y la titularidad dominical a favor de la Comunidad Autónoma, dando lugar al amojonamiento y sin que las inscripciones en el registro de la propiedad puedan prevalecer frente a la naturaleza demanial de los bie nes deslindados"

\footnotetext{
${ }^{1}$ Juan Antonio CARRILLO DONAIRE. "Facultades y Prerrogativas para la defensa de los patrimonios públicos. La investigación. El deslinde".Trabajo publicado en el libro colectivo Comentarios a la Ley 33/2003, de Patrimonio de las Administraciones Públicas, coordinado por la Profa. Carmen Chinchilla María, Thomson-Civitas, Madrid, 2004, pp. 323 a 369.
} 
De lo expuesto en el precepto se deduce que el deslinde de vías pecuarias presenta unas peculiaridades que lo hacen distinto al deslinde de otros bienes demaniales, y que lo alejan de la configuración tradicional del deslinde a la que hemos hecho referencia. Dos son las peculiaridades esenciales que van a modular sus efectos y su régimen jurídico:

a) Por un lado, la especial intensidad de sus efectos, ya que el deslinde de vía pecuarias no solo va a declarar la posesión sino la titularidad dominical, prevaleciendo incluso sobre las inscripciones registrales que se le opongan. En este aspecto, sobre el que volveremos más adelante, la Ley de Vías Pecuarias, lo que hace es trasladar lo ya dispuesto en la Ley de Costas en su art. 13 para el deslinde de costas, y posteriormente el Texto Refundido de la Ley de Aguas de 20 de Julio de 2001 en su art. 95).

b) En segundo lugar, lo que si es una especialidad del régimen de autotulela de las vías pecuarias es que el deslinde no se configura como un acto aislado e independiente, sino interrelacionado y unido a una cadena de actuaciones, en especial la clasificación de vías pecuarias a la que está vinculado y cuyo contenido ha de seguir fielmente.

. El art. 5 de La Ley 3/1995 enumera las potestades de defensa, conservación y administración de las vías pecuarias que corresponden a las Comunidades Autónomas en los siguientes términos:

"Corresponde a las Comunidades Autónomas, respecto de las vías pecuarias:

a) El derecho y el deber de investigar la situación de los terrenos que se presumen pertenecientes a las vías pecuarias.

b) La clasificación.

c) El deslinde.

d)El amojonamiento."

Lo importante de esta enumeración de potestades de protección y conservación de las vías pecuarias es que se trata de funciones que están interrelacionadas en cuanto que unas constituyen la legitimación y el fundamento de las otras.

En concreto, el artículo establece como primera fase y con carácter obligatorio al configurarla como un deber, la investigación de la propia existencia y situación de la vías pecuarias, ya que sólo la constatación y acreditación de su existencia y configuración puede legitimar y fundamentar la posterior cla- 
sificación que el acto de deslinde ha de seguir fielmente. Esta dependencia de la clasificación previa, esta relación de vinculación deslinde-clasificación, que no existe en otros bienes de dominio público, hace que el acto de deslinde de vías pecuarias tenga una especial configuración frente al deslinde de otros bienes de dominio público, incluso modula, como vamos a exponer las posibilidades de impugnación y el control judicial del deslinde.

Por ello es absolutamente indispensable, aun cuando el título de esta ponencia es sólo el deslinde de vías pecuarias, que hagamos una especial referencia al acto previo de clasificación y a esta nueva relación clasificación-deslinde.

\section{LA CLASIFICACIÓN DE VÍAS PECUARIAS Y SU RELACIÓN CON EL DESLINDE}

El art. 7 de la Ley de Vías pecuarias (art. 12 del Decreto andaluz 155/1998) define la clasificación de vías pecuarias en los siguientes términos:

"La clasificación es el acto administrativo de carácter declarativo en virtud del cual se determina la existencia, trazado anchura y demás características físicas generales de cada vía pecuaria"

Dos son las notas esenciales que conforme al precepto configuran la clasificación de vías pecuarias: por un lado que su misión esencial es determinar la existencia de la vía pecuaria, justificarla; por otro lado, que sus efectos son de carácter meramente declarativo, es decir que la clasificación no constituye la vía pecuaria, sino que declara que su existencia ha quedado constatada mediante el cumplimiento del correspondiente deber de investigar. Sobre estos dos extremos hemos de hacer una serie de reflexiones:

\section{2.a) Función y contenido de la clasificación}

En primer lugar, en cuanto al contenido de la clasificación es fundamental que la misma declara la propia existencia de una vía pecuaria pero, esa existencia ha de venir justificada por una fase de investigación sería y profunda en la que quede constatado documentalmente y mediante cartografía que la vía pecuaria existe, y cual es su anchura y trazado. Por tanto lo que hace la clasificación es simplemente declarar una realidad que consiste en que hay una vía pecuaria y cuales son sus dimensiones y caracteres. Tradicionalmente (con el RDL de 1924, el Decreto de 1944 y la Ley de Vías pecuarias de 1974), la clasificación de vías pecuarias declaraba qué vías pecuarias eran innecesarias, y qué 
sobrantes había, de forma que estos bienes pasaban a ser enajenados; actualmente estas funciones de la clasificación han desaparecido y la Ley de Vías Pecuarias (art. 10) y el 31 del Reglamento andaluz regulan el procedimiento específico de desafectación de las vías pecuarias previa acreditación de que las mismas no son adecuadas al tránsito de ganado, y que no pueden destinarse a los otros usos compatibles o complementarios previstos en las referidas normas.

Ahora bien, no podemos desconocer que a la vista de la amplitud dada al concepto de vías pecuarias por la Ley 3/1995, la clasificación ha adquirido una nueva proyección: tradicionalmente las vías pecuarias eran bienes de dominio público vinculados al uso pecuario; una vez que la función pecuaria de estos caminos se ha ido reduciendo (por los cambios en la cría de ganado, los sistemas de comunicación, transportes y en definitiva la evolución de las técnicas de explotación ganadera) la revitalización y el mantenimiento de la demanialidad y la función pública de las vías pecuarias requieren que se destinen a nuevas funciones, que la Ley de Vías pecuarias ha recogido y que consisten fundamentalmente en una función ecológica, ocio y esparcimiento y una función socio-cultural. Es decir al margen del uso pecuario que justifica en primer lugar el carácter demanial de las vías pecuarias, existen otros usos o funciones sociales -la protección de del medio ambiente, del patrimonio histórico...- que en la nueva Ley justifican el mantenimiento de la demanialidad de estos bienes. De esta forma, la clasificación en su función de declarar la existencia de una vía pecuaria ha de justificar no sólo que la vía pecuaria existe y ha existido, con qué anchura y con qué trazado -para lo que, como hemos dicho es esencial el cumplimiento del previo deber de investigar- sino que el mantenimiento de su existencia como bien demanial impone que quede justificado que la misma se destina a uno de estos usos que de forma generosa ha descrito la Ley 3/1995, y que permiten mantener el carácter demanial más allá del mero uso pecuario.

2.B) Efecto meramente declarativo de la clasificación de vías pecuarias: importancia esencial de la fase previa de investigación

En segundo lugar, en cuanto al efecto declarativo de la clasificación hemos de tener en cuenta que la jurisprudencia en ocasiones se ha mostrado dudosa o contradictoria en esta cuestión.

En efecto, hay sentencias en las que parece reconocerse que la vía pecuaria no existe en tanto que la misma no es clasificada y posteriormente deslindada, y que, por tanto no puede aplicarse el régimen de protección de las mismas, en especial el régimen sancionador. Es el caso entre otras de la Senten- 
cia del Tribunal Superior de Justicia de Madrid de 16 de febrero de 2001 (Arz. 207316) y del Tribunal Superior de Justicia de Extremadura de 14 de Octubre de 1997 (Arz. 2233), en las que se declaraban nulas sanciones administrativas impuestas por la comisión de infracciones en materia de vías pecuarias en terrenos que aun no estaban clasificados, en esas Sentencias se entendía que al no existir clasificación no era aplicable el régimen sancionador en materia de vías pecuarias. Asimismo la Sentencia del Tribunal Superior de Justicia de Andalucía de 22 de Diciembre de 2003 (Arz. 340/04) dispone: "El acto de clasifi cación es necesario para que la vía pecuaria sea considerada jurídicamente como de do minio público, y mientras que esa clasificación no se haya producido no serán de aplicación las reglas jurídicas de protección especial del dominio público”.

Si embargo el carácter constitutivo de la clasificación es totalmente opuesto a la propia literalidad de nuestra Ley de Vías Pecuarias que en su art. 7, como hemos visto, dice expresamente que la clasificación tiene efectos meramente declarativos. Lo que hace, por tanto, la clasificación de vías pecuarias es concretar en bienes específicos la afectación genérica al dominio público de las vías pecuarias que se hace en la Ley, pero la clasificación no constituye la vía pecuaria, ni declara el dominio sobre la misma, sino que sólo recoge formalmente su prexistencia que previamente ha de haber sido constatada mediante una fase de investigación cuyo resultado es el que se recoge y traslada a la clasificación. Más allá de esta declaración de existencia de la vía pecuaria, la clasificación no tiene efectos. Es decir, la declaración de la existencia de una vía pecuaria recogida en la clasificación queda latente y a la espera de que mediante el deslinde esa afectación se concrete aun más sobre la realidad de los terrenos con efectos, ya sí, declarativos del dominio, ahora bien, el deslinde no innova el contenido de la clasificación sino que lo aplica en la realidad con efectos distintos y más intensos.

\section{C) Relación Clasificación-Deslinde}

A la vista de lo expuesto, hemos de concluir que la relación o el binomio clasificación-deslinde, se muestra como una relación compleja y, en ocasiones contradictoria a la que la práctica además está dando unos efectos indeseables:

En el ejercicio de las potestades de autotutela de los demás bienes de dominio público, como es el caso de las costas -por referirnos a los bienes de dominio público, cuyo deslinde guarda mayor semejanza con el de las vías pecuarias- la afectación al dominio público se hace en la Ley (art. 132 de la Constitución) al describir los caracteres del bien, de forma que aquellos bienes de la realidad que cumplan las condiciones descritas en la Ley pasan a formar 
parte del demanio, y luego el acto de deslinde concreta esa afección en la realidad produciendo el efecto declarativo del dominio,-como es el caso de las costas-, o bien meramente declarativo de la posesión, según los casos.

Sin embargo en la Ley de Vías pecuarias, entre la afectación genérica hecha en la Ley y la declaración del dominio público sobre los bienes concretos hecha en el deslinde, hay un paso intermedio que es la clasificación que meramente declara la existencia de un bien que cumple las exigencias establecidas en la ley para ser vía pecuaria pero sin afirmar y declarar su carácter demanial. Por tanto, la función de concretar la afectación y declarar el carácter demanial que, respecto de otros bienes de dominio público, se hace en el acto de deslinde, en el caso de las vías pecuarias se descompone en dos procedimientos, en dos actos y, lo que es peor momentos distintos: la clasificación y el deslinde.

La Ley de Vías pecuarias, parece que ha tenido presente la dificultad de investigar y constatar la existencia de las vías pecuarias actualmente en desuso como caminos para el tránsito de ganado, y la necesidad de conocimientos específicos para su indagación, y a tal fin, la Clasificación parece estar concebida como un trabajo preparatorio del deslinde, ahora bien, sus efectos sobre el mismo al que vincula de forma absoluta exceden de un mero trabajo preparatorio; el contenido del deslinde es conocido desde que se aprueba la clasificación, de la que el deslinde no puede desmarcarse, las vías pecuarias que existen en la realidad están determinadas desde la aprobación de la clasificación, sin embargo, no se da a la clasificación el efecto declarativo del dominio, sino que se deja para un momento posterior del deslinde. Y el mayor problema que se está haciendo patente en la realidad es que las clasificaciones no tienen un plazo de caducidad para su ejecución en la práctica mediante el deslinde.

En la práctica, la Junta de Andalucía y casi la totalidad de las Comunidades Autónomas que están llevando a cabo deslindes de vías pecuarias han acudido a una técnica que consideramos peligrosa y abusiva, y que pone en jaque el derecho a la defensa:

a) En lugar de cumplir el deber de investigar la existencia de las vías pecuarias, se están remitiendo a clasificaciones preconstitucionales hechas por el Ministerio de Agricultura en los años 50 y 60; para ello se basan en que estamos ante actos firmes y consentidos plenamente aplicables. Sin perjuicio de que más adelante volveremos sobre esta cuestión, y en concreto sobre la validez o no de esas clasificaciones, es necesario tener presente dos circunstancias 
que determinan necesariamente, si no la caducidad propiamente dicha de estas clasificaciones puesto que no está prevista, sí el desfase de sus contenidos:

-En primer lugar, como ya hemos dicho, la nueva Ley de Vía pecuarias ha dado una mayor amplitud a los fines que legitiman el mantenimiento de la demanialidad de las vías pecuarias. En las clasificaciones antiguas que están aplicándose, muchas de las vías pecuarias que se recogen actualmente están en desuso como caminos pecuarios, por lo que el hecho determinante de su demanialidad conforme a la clasificación no existe en la realidad; la clasificación ha quedado desfasada y, conforme a la nueva Ley de Vías Pecuarias, una nueva clasificación ha de fundamentar la existencia de la vía pecuaria justificando la concurrencia de los fines que conforme a la nueva Ley permiten mantener su carácter demanial (protección del medio ambiente, protección del patrimonio histórico, ocio, esparcimiento, comunicaciones agrarias....). Es decir una de las características esenciales que configuran la existencia de la vía pecuaria, esto es su uso pecuario se ha desvanecido por lo que la clasificación, necesariamente en su contenido pierde vigencia y deviene inexacto.

-En segundo lugar, las clasificaciones que se está aplicando recogen en muchos casos vías pecuarias que habían sido adquiridas por usucapión por propietarios particulares, por lo que se prescinde de la garantía expropiatoria establecida por el art. 33.2 de la Constitución. El dominio público sobre las vías pecuarias se ha concebido siempre como un dominio público relajado, en el que las notas de inalienabilidad e imprescriptibilidad no han regido plenamente, así las regulaciones anteriores admitía la prescripción adquisitiva por la posesión continuada durante 30 años.

-Por otro lado, el tiempo trascurrido desde que se aprobaron estas clasificaciones y el avance, producido en la organización de los archivos y fondos documentales y el pleno reconocimiento del derecho de los ciudadanos a acceder a los mismos -derecho que en la época en que se hicieron las clasificaciones aun no estaba reconocido plenamente- ello ha hecho que aflore el conocimiento de documentos históricos antes inaccesibles entre los que la Clasificación de las vías pecuarias ha pasado a ser es uno más de esos documentos a tener en cuenta en el deber de investigación que, conforme al art. 5 de la Ley de Vías Pecuarias corresponde a la Administración Autonómica ${ }^{2}$. La

\footnotetext{
${ }^{2}$ El reconocimiento del derecho de los ciudadanos a acceder a los archivos y registros es una conquista reciente. En efecto, como se pone de manifiesto en los estudios doctrinales, en la época en la que se elaboraron las clasificaciones de los años 50 y 60 que viene aplicando la Junta de
} 
perspectiva del tiempo y los avances en los conocimientos históricos han dado una nueva dimensión a estas clasificaciones que se han convertido en una más de las muchas fuentes históricas que existen, pero no en las únicas.

A pesar de ello, existen numerosas sentencias en las que se reconoce la procedencia de la aplicación de las clasificaciones antiguas hechas en los años 50 y 60 , entre ellas podemos destacar, las sentencias del Tribunal Superior de Justicia de Extremadura de 20 de Junio de 2005 (arz. 173111), de 23 de Mayo de 2005 (Arz. 137669), de 23 de Mayo de 2005 (Arz. 169278), de 19 de Mayo de 2005 (Arz. 128098), de 19 de Mayo de 2005 (Arz. 128100), de 19 de Mayo de 2005 (Arz. 128107), de 23 de Mayo de 2005 (Arz. 169272), de 24 de Mayo de 2005 (Arz. 137661), de 25 de Mayo de 2005 (Arz. 137622) y el tribunal Superior de Justicia de Andalucía ha dictado sentencia de 19 de Junio de 2000 (Arz. 76211) en el mismo sentido.

"Existen multitud de actos administrativos dictados en el período de 1936-1975, que en nada se ven afectados por la entrada en vigor de la CE de 1978, precisamen te por razones de legalidad y seguridad jurídica, sin que pueda alegarse válidamen te, que por la entrada en vigor de la CE de 1978 quedasen sin efecto todos los actos administrativos dictados en ese periodo. La realización del acto de deslinde sobre la base de la clasificación de esa fecha, es una consecuencia ordinaria del mismo como hemos expuesto. No concurre causa de nulidad por ausencia de clasificación previa

Andalucía, el derecho a acceder a los archivos y registros no estaba reconocido ni en consecuencia tenía el grado de desarrollo y consolidación que tiene actualmente.

Los antecedentes legislativos de aquella época se reducen a un Reglamento por el que se reguló el "Régimen y Gobierno de los Archivos del Estado", que fue aprobado por Real Decreto de 22 de Noviembre de 1901, en el, que por primera vez se regulan los archivos históricos y administrativos, si bien no existe un reconocimiento del derecho de los administrados a consultarlos, sino un régimen restringido de acceso a los mismos reservado únicamente para los miembros de la Administración, que se fue acentuando con las normas elaboradas en cada uno de los departamentos ministeriales. Hay que esperar hasta la Orden del Ministerio de Educación Nacional de 4 de Marzo de 1959, por tanto posterior a la fecha de algunas de las clasificaciones aplicadas por la Comunidad Autónoma, para que se hiciera una cierta regulación del derecho a consultar ciertos archivos pero reservado únicamente a "investigadores"; se trata del Archivo Histórico Nacional, los Generales de Simancas, Corona de Aragón e Indias y los regionales, así como algunos de distritos, en los que ahora se han encontrado documentos que dan una imagen fiel de las vías pecuarias, y que en esa época su lectura e investigación estaba muy restringida, permitiéndose sólo a personas que obtuvieran una autorización especial concedida discrecionalmente por la Administración. Por su parte, la Ley de Procedimiento Administrativo de 1958, al igual que la Ley de 1889, omite el reconocimiento y la regulación de un derecho subjetivo de acceso a los archivos y registros. 
por ausencia de clasificación previa, en tanto que tal acto existe, y del hecho de ha berse verificado en 1960 no debe derivarse su nulidad. La recurrente, por otra parte, no denuncia inexactitudes de aquella Orden u otros antecedentes documentales que pu diesen ponerle en tela de juicio en cuanto al trazado"

Todas estas sentencias se basan en que la antigüedad de la clasificación no determina su inaplicación pero no entran a valorar lo que ocurriría si además de antiguas, se tratara de clasificaciones viciadas de nulidad. Más adelante volveremos sobre ello.

En todo caso, y como propuesta de lege ferenda sería procedente que la legislación impusiera un plazo máximo de validez de las clasificaciones o un plazo de caducidad a fin de evitar que perdurara la eficacia de actos administrativos, cuyos contenidos han quedado desfasados por las nuevas circunstancias de hecho y los nuevos conocimientos.

b) A la antigüedad de las clasificaciones que vienen aplicándose se une además la falta de garantías con las que muchas de ellas se tramitaron, cuestión sobre la que volveremos más adelante cuando analicemos la impugnación del deslinde, y es que con el pretexto de que la norma reguladora de las vías pecuarias vigente cuando se hicieron las clasificaciones antiguas, -en concreto el reglamento de 1944- no exigía expresamente la audiencia a los propietarios colindantes, las mismas se hicieron con una mera información pública sin notificar personalmente a los propietarios colindantes, que en su momento no conocieron de la existencia de estas clasificaciones y no pudieron interponer los recursos procedentes. Ello unido a que hasta ahora no se han llevado a cabo los deslindes de las vías pecuarias determinaron que aquellas clasificaciones quedaran supuestamente firmes y consentidas.

Ahora bien, aunque no estaba establecido en la normativa específica de Vías pecuarias de la época la necesidad de dar audiencia a los propietarios colindantes, la Ley de 19 de Octubre de 1889 que regulaba las Bases del Procedimiento Administrativo a desarrollar por los distintos Ministerios si lo imponía (art. 10.2: "Instruidos y preparados los expedientes para su resolución, se comuni carán a los interesados para que dentro del plazo que se señale, y sin que pueda bajar de diez días ni exceder de treinta, aleguen y presenten los documentos y justificaciones que consideren conducentes a sus pretensiones"), y posteriormente también la Ley de Procedimiento Administrativo de 1958 (art. 91: "Instruidos los expedientes, e in mediatamente antes de redactar la propuesta de resolución, se pondrán de manifiesto a los interesados, para que en un plazo no inferior a diez dias ni superior a quince, ale guen y presenten los documentos y justificaciones que estimen pertinentes") y además es 
abundante la jurisprudencia preconstitucional anterior a la fecha de la Clasificación que declara la trascendencia y la necesidad del trámite de audiencia por su relación al derecho a la defensa y al principio de que nadie puede ser condenado sin ser oído.

En este sentido es destacable la Sentencia del Tribunal Supremo de 27 de Marzo de 1984, que resume evolución jurisprudencial desde antes de la Constitución sobre esta materia:

"La cuestión debe ser abordada partiendo de la verdadera naturaleza del trámite de audiencia y de la motivación teleológica que constituye su razón de ser, se trata de un trá mite que ha sido considerado como de observancia obligatoria -STS de 13 de Mayo de 1948-, de extraordinaria importancia -STS de 4 de Marzo de 1947-, necesario -STS de 25 de Abril de 1950-, más cualificado-STS de 29 de Marzo de 1943, cardinal-STS de 2 de Marzo de 1931-, sustancial-STS de 11 de Julio de 1932-, fundamental-STS de 12 de Febrero de 1951-, capital-STS de 13 de Enero de 1905-, esencial-STS de 7 de Marzo de 1950-, esencialísimo -STS de 27 de Mayo de 1935-, sagrado -STS de 15 de Junio de 1925; es un trámite del que se puede decir todo esto porque obedece a un eterno principio de justicia, que exige que nadie pueda ser condenado sin ser oído -STS de 15 de Noviem bre de 1934-, lo que justifica que el principio se aplique en todas las jurisdicciones-SSTS de 20 de Mayo de 1903, de 23 de Abril de 1932, de 28 de Junio de 1933, de 5 de Febre ro de 1947-, y que haya formado parte de nuestro derecho histórico; llegando a alcanzar rango constitucional en nuestra ley fundamental de 27 de Diciembre de 1978"

Actualmente, aunque nos parezca increíble, la cuestión de si la audiencia a los propietarios colindantes en el expediente de clasificación es preceptiva o no sigue planteando dudas:

La Ley de Vías Pecuarias del Estado no exige la notificación y audiencia a los propietarios colindantes en el procedimiento de aprobación de la clasificación y, sin embargo, sí lo hace expresamente para el expediente de deslinde. Teniendo en cuenta que la clasificación, como hemos expuesto, determina ya el contenido del deslinde, es, por tanto, en el momento de hacer la clasificación donde los propietarios afectados han de tener la posibilidad de alegar lo que tengan por conveniente y presentar documentos en defensa de sus derechos y no con posterioridad cuando, en el acto de deslinde el contenido de la clasificación vincula de manera absoluta, sin tener además, como vamos a ver, posibilidad de impugnarlo. En definitiva, de nada vale un trámite de audiencia en el expediente de deslinde si cuando se estableció su contenido los particulares propietarios colindantes afectados no tuvieron la oportunidad de intervenir; la indefensión es absoluta. 
El Reglamento Andaluz de Vías Pecuarias tampoco es lo suficientemente claro y contundente al respecto ya que habla de audiencia a los interesados, entre los que es lógico pensar que tienen que estar incluidos los propietarios colindantes afectados por la clasificación. Sin embargo de la literalidad de la norma parece deducirse que la intención ha sido otra, ya que cuando se regula el trámite de audiencia en el expediente de deslinde, el Reglamento se remite a lo ya expuesto para el procedimiento de clasificación y, además, dice que en todo caso se considerarán como interesados los propietarios colindantes, Ayuntamientos afectados y las organizaciones que representen la defensa del medio ambiente, como si estos no tuvieran que ser necesariamente considerados como interesados y notificados en el procedimiento de aprobación de la clasificación. En concreto el art. 20 del Decreto andaluz 155/1998 establece:

"A los efectos de lo establecido en el apartado 2 del citado artículo y de acuerdo con lo dispuesto en el art. 8.7 de la LVP. Además de aquellos otros que puedan gozar de la condición de interesados en el procedimiento, se considerarán en todo caso como tales al Ayuntamiento correspondiente, los propietarios colindantes y las organizaciones o colec tivos interesados cuyo fin sea la defensa del medio ambiente".

Por otro lado, no podemos desconocer que un efecto esencial del inicio del expediente de clasificación es que se legitima al personal de la Administración para entrar en las propiedades colindantes con las supuestas vías pecuarias para desarrollar las operaciones precisas para la elaboración de la clasificación, y para ello, se exige la notificación a esos propietarios colindantes. El propio Tribunal Superior de Justicia de Andalucía, en la sentencia de 11 de abril de 2001 (Arz. 1428) dictada en el recurso interpuesto contra el propio Decreto 155/1998 por el que se aprueba el Reglamento andaluz de vías pecuarias, declaró refiriéndose a los efectos del inicio del expediente de clasificación, "el acceso a las fincas privadas habrá de venir precedido de la notificación in dividual al propietario que ha tenido intervención previa al inicio del expediente y que podrá alegar los motivos de oposición que tenga si existieran, y como dice la demanda no significa que el acceso pueda hacerse contra la voluntad del propietario". Esta sentencia fue confirmada por el tribunal Supremo en Sentencia de 15 de Noviembre de 2004 (Arz. 7442).

A pesar de ello no podemos desconocer que existen sentencias que han declarado válidas y plenamente aplicables clasificaciones de vías pecuarias realizadas sin dar audiencia a los propietarios afectados. Es el caso de la Sentencia del Tribunal Superior de Justicia de Madrid de 4 de Diciembre de 2002 (Arz. 1391/94), que declara válida la clasificación realizada conforme al Reglamento de 1978 sin dar audiencia a los propietarios colindantes, admitien- 
do asimismo la validez de una reforma de la clasificación hecha ya en 1995 también sin audiencia por entender que la normativa aplicable es la de 1978:

"Pero es que además y en todo caso, la recurrente parece desconocer que el regla mento de vías pecuarias de 1978, normativa vigente y aplicable cuando se inició el expediente de clasificación de la Vía Pecuaria... instruido para la determinación de la existencia y la categoría de las vías pecuarias, que es la base esencial para el conocimiento, conservación, mejora y administración de las mismas no exige la in tervención personal-ni por tanto la notificación- de los posibles articulares propie tarios de los terrenos afectados habiéndose efectuado la Clasificación que concluyó con la orden 2232/95 con arreglo a las prescripciones procedimentales previstas en dicha disposición y con la publicidad con ella exigida"

En el mismo sentido la Sentencia del Tribunal Superior de Justicia de Valencia de 19 de Octubre de 1996 (arz. 1451) declara válida la clasificación hecha bajo la vigencia de la Ley de 1974 sin da audiencia a los propietarios colindantes y dispone que, al tratarse de un acto dirigido a una pluralidad de personas basta con la publicación, y que en todo caso, para que la impugnación procediera sería preciso no sólo el vicio procedimental sino la indefensión real de tales propietarios.

Y lo que es peor es que, no sólo se ha declarado la validez de las clasificaciones hechas sin dar audiencia en base a normas anteriores a la vigente y preconstitucionales, sino que incluso se ha admitido la validez de clasificaciones hechas sin notificar a los propietarios afectados bajo la vigencia de la Ley de Vías Pecuarias actual de 1995. En concreto la Sentencia del Tribunal Superior de Justicia de Andalucía de 22 de Diciembre de 2003 (Arz. 340/04) así lo ha mantenido, ahora bien, el efecto generador de indefensión que ello acarrea lo trata de corregir permitiendo, como veremos más adelante, que puedan alegarse frente al acto de deslinde en la impugnación ante la jurisdicción contencioso-Administrativa cuestiones relativas a los derechos civiles sobre los terrenos deslindados, cuando se trata de adquisiciones que resulten acreditadas de forma notoria e incontrovertida.

Se trata de una solución inadmisible que produce un aumento de la litigiosidad en la materia. En lugar de reconocer la necesidad de la notificación y audiencia a los propietarios colindantes en el expediente de clasificación para garantizar el derecho a la defensa, trata de sustituirse este trámite imponiendo a estos propietarios afectados el deber de impugnar el acto de deslinde para hacer valer sus derechos. Ha de reflexionarse sobre esta cuestión y exigir la notificación a los propietarios colindantes interesados en el procedi- 
miento de clasificación sin lugar a dudas, otra solución es contraria al derecho a la defensa (art. 24 de la Constitución) y a los principios de transparencia, buena fe y confianza legítima que han de regir la actuación de la Administración (Art. 3 de la Ley 30/92 de Régimen Jurídico de las Administraciones Públicas y Procedimiento Administrativo Común).

En la práctica la situación actual es un claro reflejo de los efectos perniciosos que la falta de notificación a los propietarios colindantes provoca: la Administración andaluza está realizando el deslinde de las vías pecuarias en base, como hemos dicho a clasificaciones elaboradas en los años 50 y 60 en las que no se dio audiencia a los propietarios afectados que, por tanto no pudieron impugnarlas al desconocer su existencia, y, ahora, cuando al recurrir los deslindes de vías pecuarias se impugna el contenido del mismo, tanto la Administración como los Tribunales han venido rechazando estos motivos por entender que no puede discutirse a través del recurso contra el deslinde el contenido de la clasificación que es un acto firme y consentido al no haber sido impugnado en su momento. La indefensión es absoluta.

\section{EL DESLINDE DE LAS VÍAS PECUARIAS}

3.a) Concepto y naturaleza del deslinde de Vías Pecuarias en su pespectiva histórica

Tradicionalmente, como hemos visto, el deslinde de bienes de dominio público se ha concebido como un acto por el que se declaran los límites de los bienes de dominio público respecto de las propiedades colindantes, constatándose así una situación fáctica de posesión, pero sin que el deslinde calificara jurídicamente el título o derecho que fundamenta esa posesión.

De esta forma, el deslinde habría de ser respetuoso con las inscripciones registrales amparadas por la presunción posesoria del art. 38 de la LH para cuya destrucción era preciso acudir a los Tribunales a los que se encomienda en el art. 1 de la LH la protección de los asientos del Registro.

En los límites de esa concepción tradicional del deslinde de bienes de dominio público, el deslinde de vías pecuarias ha tenido siempre una serie de connotaciones especiales, algunas de las cuales se mantienen aun en la Ley 3/1995:

a)Durante años las normas que se han ido sucediendo en la regulación del deslinde de vías pecuarias lo han concebido no sólo como un acto de de- 
claración del estado posesorio y de fijación de los límites de los bienes, sino como un medio para reivindicar y recuperar las vías pecuarias usurpadas. Así ocurría en los Reales Decretos de 1877 y 1892 -en ellos el deslinde se inicia con la denuncia de la usurpación-, en el Real Decreto Ley de 1924, y luego con el Decreto de 1944, hasta que finalmente el Reglamento de 1978 de desarrollo de la Ley de 1974 lo configura como un acto de fijación de los límites de los bienes pero no como un medio de reivindicación, concepción que, como vamos a ver se mantiene en la Ley 3/1995.

b) Otra de las peculiaridades del deslinde de vías pecuarias es, como hemos dicho, su absoluta dependencia o vinculación al acto previo de clasificación; carácter este que sí se mantiene en nuestro días, pero que se estableció desde antiguo: por primera vez el acto de clasificación se reguló en el Real Decreto Ley de 1924, y las normas posteriores, el Decreto de 1944, la Ley de 1974, o más en concreto el Reglamento de 1978 no han hecho más que intensificar esa relación de dependencia entre el deslinde y la clasificación.

c) Asimismo, tradicionalmente el deslinde de vías pecuarias ha estado obligado a respetar las situaciones de posesión pacífica mantenidas por más de treinta años que quedaran acreditadas (arts. 1 del Real Decreto Ley de 1924, Base 2 del Decreto de 1931, art. 1 del Decreto de 1944, Disposición Final Primera de la Ley de 1974). Se trata, como hemos expuesto, de una especialidad del dominio público cañadiego, que ha sido concebido por la doctrina como un dominio público "relajado" frente al que cabe la prescripción adquisitiva por la posesión durante treinta años. En cualquier caso, ya sea por la necesidad de respetar esta usucapión, o ya sea porque la posesión así acreditada invertía la carga de la prueba obligando a la Administración a acudir a la jurisdicción civil para reivindicar el bien -así lo han mantenido autores como BERMÚDEZ SÁNCHEZ3-, lo cierto es que el deslinde se encontraba limitado por estas situaciones posesorias.

d) Finalmente, otra de las peculiaridades que tradicionalmente se ha reconocido al deslinde de vías pecuarias es que, a diferencia de lo que ocurre con otros bienes de dominio público, la jurisprudencia ha venido reconociendo al deslinde de vías pecuarias efectos que se imponen a las inscripciones registrales y que, por tanto vencen a la presunción posesoria del art. 38 y a la

\footnotetext{
${ }^{3}$ BERMÚDEZ SÁNCHEZ, "Imprescriptibilidad y recuperación de oficio de las vías pecuarias: un aná lisis de la disposición Final Primera de la Ley de 27 de Junio de 1974". Anuario de Derecho Civil, t. XLVI. Fascículo 1, págs 219 a 235.
} 
salvaguardia por los Tribunales de los asientos del registro.

En efecto, el Tribunal Supremo en numerosas sentencias -como la de 11 de Junio de $1946^{4}$, 4 de Noviembre de 1963, 8 de Octubre de 1978, 8 de Mayo de 1965, 21 de Marzo de 1979, 10 de Junio de $1991^{5}$, y 14 de Noviembre de $1995^{6}$ - ha mantenido que las inscripciones registrales por sí solas, si no van acompañadas de otros medios de prueba no son suficientes para oponerse frente al deslinde de vías pecuarias. Esta jurisprudencia se basa en que el dominio público no precisa estar inscrito en el Registro de la propiedad para existir, y que la presunción registral del art. 38 de la Lh es una presunción iuris tantum que puede ser desvirtuada en el expediente de deslinde.

Se trata, pues, de un efecto del deslinde de vías pecuarias de sobreponerse a las inscripciones registrales que no estaba reconocido en las normas históricas de vías pecuarias sino que se ha ido fraguando por la jurisprudencia. Sin embargo hemos de tener presente que aunque este criterio jurispruden-

\footnotetext{
${ }^{4}$ La sentencia dice expresamente respecto al efecto de las certificaciones registrales frente al deslinde, que "se imita a consignar la falta de gravámenes, lo que si bien con referencia a servidumbres de particulares pudiera de momento ser importante, no asi cuando desconoce la existencia de la servidumbre pe cuaria, que es un derecho público innegable"

${ }^{5}$ La sentencia dispone que frente al deslinde incumbe a "la actora probar la improcedencia o fal ta de adecuación del deslinde realizado y que es objeto de impugnación jurisdiccional, sin que sea asumible la presunción legal que a la Comunidad recurrente le otorga el art. 38 de la LH, como fundamento de la nuli dad o anulabilidad del deslinde efectuado, en razón a que tal presunción tiene naturaleza iuris tantum y co mo tal susceptible de prueba en contrario, lo que evidentemente acontece en el expediente administrativo para la aprobación del deslinde cuestionado, como pone de relieve la circunstancia de la existencia de una estaqui lla anterior de la vía pecuaria en la zona de aparcamiento de Torre Hirta".

“... a la Comunidad recurrente le ha incumbido acreditar el dominio de los terrenos que se reputan en el deslinde objeto de invasión de la vía pecuaria, lo que no ha acontecido aportando un principio de prueba su ficiente para acreditar que el deslinde realizado no se corresponde con el discurrir de la vía pecuaria que lo motiva, sin que a los efectos pretendidos baste con ampararse en la presunción que la inscripción registral goza, la cual por las razones expuestas carece de fuerza relevante a efectos invalidantes del acto de deslinde cuestio nado."

6 “...conforme a reiterada jurisprudencia, entre otras las sentencias de 8 de Mayo de 1965 y 21 de Marzo de 1979, la falta de constancia en el registro o en los títulos de propiedad no implica la inexistencia de la vía pecuaria, ya que las vías pecuarias no representan servidumbres de paso o carga alguna, ni derecho limitati vo del dominio, y sí son como precisa el art. 1 del decreto de 23 de diciembre de 1944, una faja de terreno de dominio público nacional o una faja o zona participe de la naturaleza propia del domino público, como re fiere la Sentencia de 4 de Noviembre de 1963, y por tanto su existencia surge de la clasificación y deslinde, que la Administración del estado hizo, en la forma y momento que las actuaciones muestran”.
} 
cial se ha ido afianzando poco a poco, existen también pronunciamientos totalmente opuestos del propio Tribual Supremo y de Tribunales Superiores de Justicia en los que se supedita la eficacia del deslinde al respeto de los títulos inscritos en el Registro de la Propiedad. Como ejemplo podemos destacar las Sentencias del Tribunal Supremo de 18 de Noviembre de $1975^{7}$ y de 10 de febrero de 1989 ${ }^{8}$, 22 de Marzo de 1990, 3 de Julio de 1991, 3 de Marzo de 1994, y 7 de Febrero de 1996, entre otras.

Vistas estas peculiaridades que tradicionalmente han conformado el deslinde de vías pecuarias procede ahora preguntarnos, ¿cómo ha quedado hoy día regulado el deslinde en la Ley 3/1995?, ¿qué función y que efectos tiene en la regulación actual el deslinde de vías pecuarias?

\section{3.b) Concepto y efecto del deslinde en la Ley 3/1995}

El art. 8.1 de la Ley de Vías Pecuarias (art. 17 del Reglamento andaluz) define el deslinde de vías pecuarias como: "el acto administrativo por el que se de -

7 «en todo expediente de deslinde administrativo ha de ser respetado el principio de legitimación registral del art. 38 de la Ley Hipotecaria, a tenor del que se presumirá a todos los efectos legales que los derechos rea les inscritos en el Registro de la Propiedad existen y pertenecen a su titular en la forma determinada por el asiento respectivo asi como también quien tenga inscrito el dominio de inmuebles o derechos reales tiene la po sesión de los mismos, no pudiendo tampoco ejercitarse ninguna acción contradictoria del dominio de inmue bles y derechos reales inscritos a nombre de persona o entidad determinada, sin que previamente o a la vez se entable demanda de nulidad o cancelación de la inscripción correspondiente, lo que viene a corroborar el pro pio art. $1 .{ }^{\circ}$ de la Ley Hipotecaria

8 "El Tribunal «a quo", con acierto entiende, que el acto recurrido es contrario al Ordenamiento Jurídico, al no ponderar los efectos que en relación con unos terrenos comprendidos dentro del perímetro del deslinde que aprueba, produce su inscripción en el Registro de la Propiedad a favor del Ayuntamiento de Segovia, dado que aparte de las situaciones juridicas amparadas por el art. 34 de la Ley Hipotecaria, a las que hace referencia el art. 94 del Reglamento de Vias Pecuarias, aprobado por el Real Decreto 2876/78, existen otras situaciones derivadas de la simple inmatriculación en el Registro de la Propiedad que no pueden ser desconocidas por la Administración al llevar a cabo la operación de deslinde de una Vía Pecuaria, dado que, el titular de la ins cripción registral, aunque no goce de la condición de tercero protegido, si se presume que tiene la posesión del inmueble cuyo dominio está inscrito a su favor; recordando al efecto la Sentencia de este Tribunal de 18 de no viembre de 1975 (RJ 197514914) que «en todo expediente de deslinde administrativo ha de ser respetado el principio de legitimación registral del art. 38 de la Ley Hipotecaria, a tenor del que se presumirá a todos los efectos legales que los derechos reales inscritos en el Registro de la Propiedad existen y pertenecen a su titular en la forma determinada por el asiento respectivo así como también quien tenga inscrito el dominio de inmue bles o derechos reales tiene la posesión de los mismos, no pudiendo tampoco ejercitarse ninguna acción contra dictoria del dominio de inmuebles y derechos reales inscritos a nombre de persona o entidad determinada, sin que previamente o a la vez se entable demanda de nulidad o cancelación de la inscripción correspondiente, lo que viene a corroborar el propio art. $1 .^{\circ}$ de la Ley Hipotecaria", sentencia en la que asimismo se declara que si bien los expedientes de deslinde, no prejuzgan cuestiones de propiedad, centrándose en la órbita posesoria 
finen los límites de las vías pecuarias de conformidad con lo establecido en el acto de la clasificación". Por tanto, en la regulación vigente, el acto de deslinde sigue siendo un acto delimitador de las vías pecuarias, que concreta sus contornos respecto de los bienes colindantes, y además, sigue siendo un acto vinculado a la clasificación previa. Como ya hemos expuesto al analizar la relación clasificación-deslinde, los efectos y funciones que en otros bienes de dominio público corresponden sólo al deslinde, en el caso de las vías pecuarias estás escindidos en dos momentos, en dos actos independientes e interrelacionados, la clasificación, -que declara la existencia de la vía pecuaria previamente acreditada mediante el cumplimiento previo del deber administrativo de investigar- y el deslinde -cuya misión es delimitar sobre la realidad la línea divisoria de las vías pecuarias con las propiedades colindantes-. Como ya dijimos, la relación entre uno y otro se basa en la absoluta subordinación del deslinde al acto de clasificación, hasta el punto de que la jurisprudencia ha llegado a afirmar que el acto de deslinde es un acto de mera ejecución de la clasificación (STS 23 de mayo de 1979).

Ahora bien, esta superioridad de la clasificación sobre el deslinde al que vincula, no se corresponde con los efectos externos que la Ley de Vías Pecuarias ha otorgado a cada uno de estos actos. Mientras que la clasificación tiene un efecto meramente declarativo de la existencia de la vía pecuaria y de su posesión por la Administración sin prejuzgar el título por el que se posee; sin embargo, el deslinde tiene un efecto declarativo del dominio que prevalece incluso frente a las inscripciones registrales que lo contradigan. El art. 8 de la Ley de Vías pecuarias en los apartados 3 y 4 se refiere a estos efectos:

"2. el deslinde aprobado declara la posesión y la titularidad dominical a favor de la Comunidad Autónoma, dando lugar al amojonamiento sin que las inscripciones del Registro de la Propiedad puedan prevalecer frente a la naturaleza demanial de los bie nes deslindados.

3.La resolución de la aprobación del deslinde será título suficiente para rectificar, en la forma y condiciones que se determinen reglamentariamente, las situaciones jurídi cas registrales contradictorias con el deslinde. Dicha resolución será título suficiente pa -

únicamente, la delimitación de los terrenos objeto de cada deslinde no pueda hacerse discrecionalmente por la Administración, sino con base y respeto a las situaciones de propiedad o posesión de los particulares en la for ma que resulta acreditada por medios probatorios o antecedentes documentales bastantes para justificar legal mente tales situaciones; por lo que no cabe desconocer la realidad de los títulos dominicales inscritos en el Re gistro de la Propiedad". 
ra que la Comunidad autónoma proceda a la inmeatriculación de los bienes de dominio público cuando lo estime conveniente. En todo caso, quienes se consideren afectados por la resolución aprobatoria del deslinde podrán ejercitar las acciones que estimen perti nentes en defensa de sus derechos y solicitar la anotación preventiva de la correspon diente reclamación judicial".

De esta forma la Ley de Vías Pecuarias de 1995 ha recogido en un texto positivo el efecto que ya venía reconociendo la jurisprudencia al deslinde de vías pecuarias de prevalecer sobre los asientos del registro. (Recordemos que ya el Tribunal Supremo en algunas sentencias había mantenido este criterio con base en que el dominio público no ha de estar inscrito para existir, y que la presunción del art. 38 de la LH es susceptible de prueba en contrario, entre otros medios con un expediente de deslinde que justifique que los terrenos corresponden a una vía pecuaria y no son de carácter privado).

Algún autor como ALENZA ${ }^{9}$ ha criticado la innecesariedad de que la Ley de Vías Pecuarias reconociera un efecto que ya era una realidad reconocida por la jurisprudencia. Frente a ello, hemos de mantener que la regulación de estos efectos en la Ley de vías Pecuarias si tiene trascendencia en cuanto a la seguridad jurídica que impone el que estén recogidos en una norma escrita y no sólo en la jurisprudencia que, por otro lado, había sido vacilante y contradictoria al respecto.

A pesar de la amplitud de los términos del precepto, la potestad del deslinde de las vías pecuarias ha de ser interpretada en sus justos términos, ya que el dar un sentido demasiado amplio y flexible a la misma podría llevar a verdaderas usurpaciones contrarias al derecho de propiedad de los particulares.

El deslinde no es un medio de adquisición de las vías pecuarias, ni siquiera un medio de recuperación de la posesión de las mismas. Para crear, ampliar o restablecer una vía pecuaria conforme al art. 6 de la Ley 3/1995, el procedimiento no es la clasificación y el posterior deslinde, sino la vía expropiatoria recogida en el art. 33.2 de la Constitución. Y para la recuperación de la posesión de las vías pecuarias el procedimiento se regula en los arts. 27 y siguientes del Reglamento Andaluz.

${ }^{9}$ ALENZA GARCÍA, JOSÉ FRANCISCO. Vías pecuarias. Gobierno de Navarra. Departamento de Medio Ambiente, Ordenación del Territorio y Vivienda.2001. 
Sobre los efectos del deslinde en relación a los derechos de propiedad consolidados por los particulares y las inscripciones registrales, el Tribunal Superior de Justicia de Andalucía en la Sentencia de 22 de Diciembre de 2003 (Arz. 340/04) ha sido extraordinariamente clarificador sentando las siguientes pautas:

1) No es suficiente con presentar la certificación de la inscripción registral para oponerse al deslinde: La sola apariencia de legitimidad y exactitud derivada del hecho de la titularidad registral de parte del terreno deslindado a favor del particular, no es oponible ni en la vía civil, ni en la vía contencioso-administrativa en materia de deslinde. Prevalece el deslinde y por ello la Administración no se verá obligada a destruir la presunción iuris tantum de exactitud establecida en el art. 38 de la LH, sino que bastará rectificarla conforme dispone el art. 8.3 de la Ley 3/1995.

2) Por exigencia del art. 33 de la Constitución deben respetarse las adquisiciones plenas y firmes que se hayan producido con anterioridad sobre terrenos que después vayan a ser deslindados, y conforme a las normas civiles e hipotecarias vigentes en su momento. Esta adquisición se puede haber producido por tres vías:

2.a)Por enajenación realizada por la propia Administración que en el momento en que se hizo fuera competente para la clasificación y deslinde. (hemos de recordar aquí lo ya dicho sobre las funciones tradicionales de la clasificación en la que se declaraban las vías pecuarias innecesarias y terrenos sobrantes que después eran enajenados).

2.b) Por medio de usucapión, conforme al Código Civil. (que como hemos dicho se admitía respecto de las vías pecuarias).

2.c) Adquisición ex lege conforme a lo dispuesto en el art. 34 de la LH que más allá de la mera presunción de exactitud registral, comporta una adquisición inatacable para quien confiando en el registro compra a título oneroso, de buena fe a quien no es dueño pero figura como tal en el Registro.

3) Para estos dos últimos supuestos, esto es la adquisiciones por usucapión y por fe pública registral ha de diferenciarse según si la adquisición se ha producido antes o después de la clasificación, y es que en el caso de las vías pecuarias, la afectación al dominio público que de forma genérica se hace en la Ley requiere necesariamente de su concreción en bienes específicos mediante la clasificación, por ello hasta que a misma no es aprobada no puede 
entenderse aplicable el régimen de protección especial del dominio público y, por tanto sólo las adquisiciones anteriores a la clasificación ha de ser respetadas por el deslinde:

3.a) Si la adquisición por usucapió o por aplicación del art. 34 de la LH, se consumó antes de la clasificación, prevalece sobre el acto de deslinde que ha de respetarla.

3.b) Si la adquisición por usucapión o por el principio de fe pública registral del art. 34 de la LH es posterior a la clasificación juega la regla de la imprescriptibilidad del dominio público, y el deslinde prevalece sobre la adquisición sin derecho a indemnización por el particular.

En relación a estos derechos que el deslinde de vías pecuarias desconoce por considerarlos no como auténticos derechos sino usurpaciones, tendríamos que considerar que la Ley de Vías Pecuarias es inconstitucional, ya que, siguiendo lo expuesto por el Tribunal Constitucional en relación a la Ley de Costas, la garantía del art. 33 de la Constitución exige que la norma hubiera previsto una compensación por la pérdida de estos derechos como ya lo hiciera la Ley de Costas al convertir los derechos de propiedad que expropiaba en derechos concesionales.

Sí estamos de acuerdo con ALENZA ${ }^{10}$ en que La Ley de Vías Pecuarias siguiendo la inercia de lo ya realizado en la Ley de Costas, no tuvo en cuenta las peculiaridades del sistema de autotutela de las vías pecuarias en las que el deslinde esta absolutamente vinculado a la clasificación previa. De esta forma, si la clasificación no puede oponerse a las inscripciones registrales, por mucho que disponga la Ley acerca de la prevalencia del deslinde sobre el Registro, lo cierto es que en la realidad el deslinde está subordinado a lo que disponga la clasificación, que a su vez ha de respetar los asientos registrales, por lo que en teoría nunca podrá darse esta oposición entre el deslinde y el registro, -a excepción de aquellos casos, desgraciadamente abundantes en la realidad, de aplicación de clasificaciones antiguas, en las que los que los particulares no hayan podido aportar esos títulos registrales y oponerse en el momento de la clasificación, y esta ya se entendiera que es acto firme y consentido plenamente aplicable, más adelante volveremos sobre este tema-. Si el legislador pretendía dar a la potestad de autotutela el efecto de prevalecer frente a la protección

${ }^{10}$ Ob. Cit. Nota 7. 
del Registro de la Propiedad, ese objetivo no ha sido cumplido con el sistema establecido sino que los efectos reconocidos al deslinde, debían haberse adelantado al momento de la clasificación.

\section{3.c) Procedimiento de deslinde de Vías Pecuarias: especial referencia al pro- blema de su caducidad}

La Ley 3/1995 de Vías Pecuarias del Estado es muy parca en la regulación del procedimiento de deslinde, limitándose tan sólo en el apartado 7 del art. 8 a concretar la garantía de la audiencia a los interesados entre los que necesariamente se encuentran los propietarios colindantes y Ayuntamientos afectados, así como las organizaciones dedicadas a la defensa del medio ambiente (ejem: Asaja); y el apartado 6 del mismo art. 8 dispone los medios para procurar la constancia registral de la existencia del expediente de deslinde.

Tenemos pues que acudir a los arts. 18 y ss del Decreto andaluz 155/1998 que regulan de forma muy concreta el procedimiento para la aprobación de deslinde que se compone de los siguientes trámites:

Inicio: El inicio del procedimiento de deslinde, al igual que se prevé en la legislación estatal puede producirse bien de oficio ( por acuerdo del Viceconsejero de Medio Ambiente), o bien a instancia de persona interesada, que normalmente serán los propietarios colindantes con la vía pecuaria, tal y como se prevé expresa y exclusivamente en el art. 52 de la Ley de Patrimonio de las Administraciones Públicas, pero no necesariamente, ya que la legitimación para iniciar el expediente de deslinde de vías pecuarias se reconoce en el reglamento andaluz de forma más amplia que en la regulación general del deslinde de la Ley de Patrimonio de las Administraciones Públicas; en la norma andaluza se puede iniciar por cualquier persona interesada y en la normativa estatal solo por los propietarios colindantes.

En el caso de que el procedimiento se inicie a instancia de parte, siguiendo lo dispuesto en la Ley del Estado 33/2003, se condiciona el inicio del procedimiento al momento en que el particular acepte el presupuesto que la Administración le comunique para el cobro de la correspondiente tasa por el coste de las operaciones que comprende el deslinde, y que se proceda a su ingreso. Al término del expediente de deslinde, se procederá a la liquidación final de las actuaciones.

La posibilidad de que el expediente de deslinde de vías pecuarias se inicie a instancia de parte plantea dudas de constitucionalidad por dos motivos: 
por un lado, porque la potestad de deslindar es una potestad que corresponde a la Administración y no una función de la que puedan disponer los particulares; se trata de una potestad y un deber de la Administración no de un derecho de los particulares y es la Administración la que tiene el privilegio de deslindar sus bienes de los colindantes sin acudir a los Tribunales; por otro lado, la exigencia de una tasa plantea dudas en cuanto a su constitucionalidad porque el establecimiento de la misma con una mera referencia en la Ley 33/2003 de Patrimonio de las Administraciones Públicas, y un desarrollo reglamentario en el Decreto 155/1998 que no determina los elementos esenciales para su cuantificación, no cumple las exigencias que impone la reserva de Ley del art. 31 de la Constitución ${ }^{11}$.

Medidas cautelares: Iniciado el expediente de deslinde, el Reglamento de Vías Pecuarias prevé la posibilidad de que se adopten medidas cautelares que se consideren necesarias para proteger la integridad física y la situación jurídica de la vía pecuaria. Se recoge así la previsión establecida en el art. $42^{12} \mathrm{de}$ la Ley de Patrimonio de las Administraciones Públicas con carácter básico y en el art. 72 de la Ley 30/92. Estas medidas provisionales, aunque no lo prevea expresamente el Reglamento andaluz, conforme a los arts. 42.2 de la Ley 33/2003 y 72.2 de la Ley 30/92 podrán ser adoptadas incluso antes del inicio del expediente de deslinde cuando existiera peligro inminente de pérdida o deterioro de la vía pecuaria.

Ahora bien, en materia de vías pecuarias que durante tantos años se han encontrado en desuso y sin deslindar y proteger por la Administración, resulta dudoso que pueda ahora motivarse la existencia de un motivo de urgencia y el periculum in mora, que legitime la adopción de estas medidas cautelares.

\footnotetext{
${ }^{11}$ Sobre esta cuestión en relación a las tasas portuarias podemos destacar a Sentencia del Tribunal Constitucional 102/2005, de 20 de Abril sobre las tasas portuarias.

12 “Artículo 42.Adopción de medidas cautelares.

1.Iniciado el procedimiento para el ejercicio de las facultades y potestades expresadas en el artículo ante rior, el órgano competente para resolverlo podrá, de acuerdo con lo previsto en el artículo 72 de la Ley 30/1992, de 26 de noviembre (RCL 1992, 2512, 2775 y RCL 1993, 246), de Régimen Jurídico de las Administracio nes Públicas y del Procedimiento Administrativo Común, adoptar las medidas provisionales que considere ne cesarias para asegurar la eficacia del acto que en su momento pueda dictarse. 2. En los casos en que exista un peligro inminente de pérdida o deterioro del bien, estas medidas provisionales podrán ser adoptadas, con los requisitos señalados en el artículo 72.2 de la citada ley, antes de la iniciación del procedimiento."
} 
Fase de instrucción: En la fase de instrucción -para la que son competentes las Delegaciones Provinciales de la Consejería de Medio Ambiente- se desarrollan las operaciones materiales o trabajos del deslinde, que consisten en que el personal de la Administración, hace sobre los terrenos un amojonamiento provisional y se toman datos topográficos para identificar sobre el terreno las características de la vía pecuaria.

Con carácter previo al inicio de estas operaciones, al menos con 20 días de antelación se publica el acuerdo de iniciación del expediente de deslinde y las operaciones materiales en el BOP, y se procurará por la Delegación Provincial de la Consejería de Medio Ambiente que se proceda asimismo a su publicación en los boletines y tablones oficiales de las distintas entidades locales y demás Administraciones afectadas a fin de dar la mayor difusión posible al expediente de deslinde para que puedan participar en el mismo todas las personas, entidades y Administraciones interesadas.

Además es precisa la notificación personal a los interesados entre los que se encuentran los propietarios colindantes a los que se les comunicará el Acuerdo de Iniciación y la clasificación que va a aplicarse (es curioso que sea en este momento cuando se prevé expresamente la notificación de la clasificación a los propietarios colindantes, es entonces cuando actualmente los propietarios afectados por clasificaciones antiguas están teniendo conocimiento de las mismas).

Para la realización de estas operaciones materiales del deslinde, una vez notificado a los propietarios colindantes el acuerdo de inicio de las mismas y la clasificación, el personal de la Administración podrá entrar en las fincas colindantes. El Tribunal Superior de Justicia de Andalucía, en la sentencia de 11 de abril de 2001 (Arz. 1428) dictada en el recurso interpuesto contra el propio Decreto 155/1998 por el que se aprueba el Reglamento andaluz de Vías Pecuarias, se ha referido a este efecto del inicio del expediente de deslinde precisando que el mismo no elimina el derecho de los propietarios para oponerse a la entrada en sus fincas: "el acceso a las fincas privadas habrá de venir pre cedido de la notificación individual al propietario que ha tenido intervención previa al inicio del expediente y que podrá alegar los motivos de oposición que tenga si existieran, y como dice la demanda no significa que el acceso pueda hacerse contra la voluntad del propietario". Esta sentencia fue confirmada por el Tribunal Supremo en Sentencia de 15 de Noviembre de 2004 (Arz. 7442).

A estas operaciones materiales de deslinde podrán comparecer todos los interesados y formular alegaciones que constarán en el acta que se levante. Si 
en este acto se aportan por los interesados títulos inscritos en el Registro de la Propiedad sobre los terrenos que puedan ser de dominio público, se pondrá en conocimiento del Registrador, para que practique anotación marginal preventiva en el Registro de la Propiedad. Resulta contradictorio que, ya que el contenido de este deslinde se determina no en el momento de su práctica sino con la aprobación de la clasificación, y que, por tanto, la existencia de las vías pecuarias que luego serán deslindadas consta ya en el acto de clasificación; que sin embargo no contenga la norma una previsión semejante sobre la constancia registral, pero para la clasificación de las vías pecuarias ya que, con ello se está permitiendo que durante años, aprobada la clasificación y conocida por tanto la existencia de las vías pecuarias, se puedan estar realizando transmisiones a terceros de buena fe que además no se verán protegidos en su adquisición por el art. 34 de la LH ya que el dominio público es imprescriptible e inalienable, y las inscripciones registrales ceden ante el deslinde.

Fase de audiencia: esta fase se realizará de la misma forma que lo previsto para la clasificación en el art. 15.1 y 2, esto es mediante anuncios en el BOP, edictos en los tablones de los Ayuntamientos afectados, y en la propia Delegación Provincial de la Consejería de Medio Ambiente. Durante un mes ha de estar expuesto al público el expediente de deslinde, y luego se da un plazo de 20 días para la presentación de alegaciones.

Resulta sin embargo inadmisible que solo para el caso del deslinde y no para la clasificación se prevea expresamente en el apartado 1 del art. 20 la obligación de notificar a los propietarios colindantes ${ }^{13}$, Ayuntamientos y organizaciones para la defensa del medio ambiente. Como ya hemos manifestado, resulta inútil un trámite de audiencia obligado a los propietarios en el momento del deslinde en el que no pueden discutir el contenido de dicho deslinde ya predeterminado por una clasificación firme en la que no se prevé expresamente la audiencia a los propietarios colindantes. La efectividad del derecho a la defensa -a fin de evitar situaciones de indefensión como las que se están produciendo actualmente- impone el carácter obligatorio también de la noti-

\footnotetext{
${ }^{13}$ La ley lo hace además conscientemente cuando después de remitirse a lo dispuesto para la clasificación establece que en el trámite de audiencia del expediente de deslinde:

"A los efectos de lo establecido en el apartado 2 del citado artículo y de acuerdo con lo dispuesto en el art. 8.7 de la Ley de Vías pecuarias, además de aquellos otros que puedan gozar de la condición de interesados en el procedimiento, se considerarán en todo caso como tales al ayuntamiento correspondiente, los propietarios colindantes, y las organizaciones o colectivos interesados cuyo fin sea la defensa del medio ambiente"
} 
ficación a los propietarios colindantes en el expediente de clasificación, si bien la norma debía haber sido más clara y contundente al respecto.

El Tribunal Superior de Justicia de Andalucía en la Sentencia de 22 de Diciembre de 2004 (Arz. 340/04) mantiene que no es requisito necesario del acto de clasificación la audiencia a los propietarios colindantes, ahora bien, el efecto generador de indefensión que ello acarrea lo trata de corregir permitiendo como veremos más adelante que puedan alegarse frente al acto de deslinde en la impugnación ante la jurisdicción contenciosa cuestiones relativas a los derechos civiles sobre los terrenos deslindados, cuando se trata de adquisiciones que resulten acreditadas de forma notoria e incontrovertida. Volvemos a insistir en que no nos parece una solución satisfactoria porque en lugar de intensificar y regular el trámite de audiencia en la clasificación de las vías pecuarias, se obliga a los propietarios afectados a impugnar el deslinde.

Propuesta de deslinde: Contestadas las alegaciones que hayan sido formuladas durante el expediente de deslinde por los que haya comparecido, se dicta la propuesta de resolución en la que ha de contar como mínimo:

-descripción de la vía pecuaria y demás lugares asociados al tránsito de ganado.

-plano detallado.

-relación de ocupaciones.

-intrusiones y colindancias.

Previo informe del Gabinete Jurídico de la Junta de Andalucía, se dicta resolución aprobatoria del deslinde.

\section{Plazo y efecto del incumplimiento del mismo:}

El plazo máximo para resolver el expediente de deslinde es de dieciocho meses, ampliable como máximo una sola vez (art. 42 de la Ley 30/92) por la mitad del plazo inicialmente establecido.

En cuanto a los efectos de la falta de resolución en dicho plazo, la ley expresamente se refiere al caso de que el expediente de deslinde se haya iniciado a instancia de parte, produciéndose el silencio administrativo negativo.

Para el caso de que, como es lo usual, el procedimiento se inicie de oficio la cuestión aunque tanto para la doctrina como para la jurisprudencia es clara, ha sido muy discutida por la Administración de Andalucía: 
Alegada la caducidad en los recursos en vía administrativa y en vía jurisdiccional que se han entablado contra los deslindes aprobados por la Consejería de Medio Ambiente de la Junta de Andalucía, la Administración ha mantenido que la institución de la caducidad no procede cuando estamos ante expedientes de deslinde de vías pecuarias ya que entiende que, no concurren los requisitos establecidos e el art. 44 de la ley 30/92, (antes de la reforma de la Ley 4/99 el art. 43.4), porque considera que no estamos ante procedimientos que perjudiquen a los interesados sino que benefician a la colectividad.

Frente a ello, entendemos que la institución de la caducidad es plenamente aplicable a los expedientes de deslinde de vías pecuarias, ya que estamos ante un procedimiento que claramente perjudica a los particulares afectados. El argumento que mantiene la Administración, lleva a vaciar de contenido el propio artículo 44 de la Ley 30/92 al hacer inaplicable la garantía en que la caducidad consiste, ya que ciertamente por imperativo del art. 103 de la Constitución y 3 de la Ley 30/92, la Administración siempre está llamada a actuar en beneficio del interés general por lo que todo procedimiento goza de la presunción de ser beneficioso para toda la colectividad aunque pueda perjudicar a algunos interesados en el mismo -el propio procedimiento sancionador, exponente clarísimo de procedimiento desfavorable para el particular conforme al art. 44, habría que mantenerse, siguiendo el razonamiento de la Junta, que es un procedimiento favorable para la colectividad en cuanto que todos tenemos interés en que se sancionen las conductas contrarias al ordenamiento jurídico y que por tanto al mismo no sería aplicable la caducidad-.

Resulta además contradictorio que la Junta de Andalucía haya mantenido este criterio frente a las impugnaciones de los deslindes cuando ella misma ha declarado expresamente caducados expedientes de deslindes ${ }^{14}$.

\footnotetext{
${ }^{14}$ Es el caso de la Resolución de la Secretaría General Técnica de la Consejería de Medio Ambiente de 16 de Marzo de 1999 (BOJA no 42 de 10 de abril de 1999) por la que se declaró la caducidad del procedimiento administrativo de deslinde de la vía pecuaria denominada "Cañada Real de la Costa" en el término municipal de Vera en Almería, cuyo fundamento de derecho segundo establece:

"Procede estimar la reclamación de caducidad del procedimiento de deslinde objeto de la presente, aten diendo a la normativa aplicable al mismo en lo que se refiere al plazo establecido para resolver sobre su apro bación. Así el decreto 137/1993 por el que se establecen normas relativas a Procedimientos Administrativos; en su artículo único, punto $2^{\circ}$, establece un plazo de un año para resolver sobre los procedimientos de clasifi cación de las vías pecuarias, plazo que en virtud del principio de analogía, es aplicable a los procedimientos de deslinde y que se ha superado en el presente procedimiento".
} 
En todo caso frente a ello la doctrina que viene manteniendo el Tribunal Superior de Justicia de Andalucía en sentencias como la dictada el 14 de Diciembre de 2004 en el recurso 929/00, la de 8 de Febrero de 2005 en el recurso 930/2000, y la Sentencia de 26 de Abril de 2005 dictada en el recurso núm. 2694/03, es la de que la caducidad si es aplicable a los expedientes de deslinde:

"El procedimiento de aprobación del deslinde que nos ocupa fue iniciado de oficio y es susceptible de producir efectos desfavorables (los que han de ponerse en relación con los interesados en este concreto procedimiento del que deriven), ya que pueden reducir o extinguir algún derecho o facultad existente, incidiendo desfavorablemente en la esfera jurídica del destinatario, en relación a la finca de su propiedad por donde discurre la cañada que se pretende deslindar.

Ello quiere decir que el procedimiento que así lo acuerda se encuentra en el ámbito objetivo del art. 43.4 de la Ley de Procedimiento donde se regula la caducidad, institu to que obedece a los principios de seguridad jurídica, interdicción de la arbitrariedad y tutela judicial efectiva, en su manifestación como derecho a un proceso sin dilaciones in debidas con el fin de evitar que pueda recaer una resolución de gravamen o limitativa de derechos extemporánea, fuera ya de los plazos razonables que debiera esperar, que no son otros que los plazos máximos de duración del procedimiento. Habiendo reconocido el Tribunal supremo en la reciente sentencia de 2 de Noviembre de 2004, la posibilidad de que se produzca la caducidad en los expedientes de deslinde"

Aunque algunas de estas sentencias han sido recurridas y actualmente están pendientes de casación, es de esperar que el Tribunal Supremo mantenga la doctrina ya sostenida en otras sentencias como la citada de 2 de Noviembre de 2004, y la de 15 de Noviembre de 2004 (Arz. 7442) ${ }^{15}$.

En todo caso, a fin de evitar la polémica surgida en torno a la caducidad del deslinde, lo procedente hubiera sido que el Reglamento de Vías Pecuarias hubiera sido claro al respecto. Carece de explicación que para el caso de la cla-

\footnotetext{
${ }^{15}$ En concreto la sentencia dice textualmente en relación a las argumentaciones de la Juta de Andalucía en contra de la aplicación de la caducidad al procedimiento de deslinde:

"se limitó a pedir la desestimación de la demanda en este punto con un argumento tan insustancial como que el art. 43.4 de la LPAC no era aplicable al no poder considerarse los expedientes en materia de vías pecuarias como susceptibles de producir efectos desfavorables para los administrados”
} 
sificación expresamente se disponga que la no resolución en plazo determina la caducidad, y para el deslinde iniciado de oficio se guarde silencio al respecto.

\section{IMPUGNACIÓN DEL DESLINDE}

El deslinde, como estamos viendo, es un acto administrativo que como tal esta sujeto a requisitos y plantea cuestiones de Derecho Público, si bien, por otro lado, se trata de un acto que decide cuestiones relativas al derecho de propiedad, declara el dominio sobre un bien alterando incluso, como hemos visto, las situaciones registrales existentes. Este doble carácter del deslinde como acto administrativo, cuyo contenido afecta al derechos civiles, determina la competencia tanto de la Jurisdicción Contencioso-administrativa como de la Jurisdicción Civil para conocer de las cuestiones relativas al mismo ${ }^{16}$ :

\section{4.a) Competencia del Orden Jurisdiccional Civil}

Los propietarios afectados por el deslinde, por tanto pueden acudir a la JURISDICCIÓN GIVIL en el ejercicio de las acciones civiles sobre los derechos relativos a terrenos incluidos en el dominio público deslindado. Para el ejercicio de estas acciones al art. 8.6 de la Ley de Vías Pecuarias establece un plazo de prescripción de cinco años desde el momento de la aprobación del deslinde, plazo de prescripción que no queda interrumpido por la impugnación en vía administrativa del deslinde o la interposición del recurso conten-

\footnotetext{
${ }^{16}$ Sobre ello los límites de la competencia de una y otra jurisdicción, la Sentencia del Tribunal Superior de Justicia de Castilla la Mancha de 17 de Febrero de 2003 (Arz. 112349) dispone:

"La función de la Jurisdicción Contencioso-administrativo, en supuestos como el presente, no es la de declarar el derecho de propiedad ni el de posesión sino el verificar que el ejercicio de la potestad de deslinde se ha ejercido conforme a las normas de Derecho Administrativo, de ahí que la regulación de los arts 14 de la Ley de Patrimonio del Estado de 1964 y 24.2 del reglamento de Vías Pecuarias de 1878, s'-lo contemplan la posibilidad de impugnar ante los Tribunales de este Orden Jurisdiccional por motivos de procedimiento, remitiendo a los tribunales civiles las cuestiones relativas a la propiedad o la posesión.

Ello no significa que en el ejercicio de la potestad de deslinde, la administración no deba tener en cuenta ciertas reglas civiles, como las relativas a los títulos sobre la propiedad o la posesión alegados por los interesados que participen en el procedimiento de deslinde, por lo que en este caso, si no los tiene en cuenta adecuadamente, el acto aprobatorio del deslinde sí que podía ser impugnado en recurso Contencioso-Administrativo, por lo que esta Jurisdicción aplicaría las normas civiles en los términos del art. 4 de la LJCA como cuestión prejudicial”.
} 
cioso-administrativo contra el mismo ya que se trata de dos vías de defensa distintas. ${ }^{17}$

Es, asimismo, doctrina jurisprudencial constante y reiterada, que las cuestiones relativas a la titularidad dominical han de ser conocidas por la Jurisdicción Civil y no por los Tribunales de lo Contencioso -entre otras podemos destacar la Sentencia del Tribunal Supremo de 27 de abril de 1999 (fundamento de derecho tercero) ${ }^{18}$-. Ahora bien el propio Tribunal Supremo ha reconocido la posibilidad de que los Tribunales de lo Contencioso, en el marco de un proceso en el que se decide sobre la legalidad o no de un acto de deslinde, puedan resolver como cuestión prejudicial con los límites del art. 4 de la Ley Jurisdiccional -la decisión no producirá efectos fuera del proceso en que se dicte y no vinculará al orden jurisdiccional competente-, las cuestiones relativas a la titularidad dominical de los terrenos supuestamente incluidos en la vía pecuaria. En concreto la Sentencia del Tribunal Supremo de 15 de Octubre de 2004 (Arz. 6345) dispone:

"Finalmente opone la parte recurrente como tercer motivo de casación, infracción del art. 1959 del Cc, puesto que a su juicio la posesión del terreno objeto del des linde durante el tiempo y con las condiciones establecidas en ese precepto determina que ha adquirido el dominio del mismo por prescripción. La sentencia de instan cia contestó a esa misma alegación declarando que se trataba de una cuestión ci vil que no podría ser resuelta por la Jurisdicción Contencioso-administrativa, y ad vierte que para que pudiera ser apreciada con carácter prejudicial, según lo pre visto en el art. 4 LJCA, sería preciso que el autor hubiera acreditado esa pose sión sobre el terreno disputado o al menos su título de propiedad inscrito en el Registro de la Propiedad. Frente a este razonamiento, la parte recurrente aparte de

\footnotetext{
17 CALERO RODRÍGUEZ, Régimen Jurídico de las costas españolas, Aranzadi, Pamplona, 1995.

${ }^{18}$ La sentencia dice textualmente:

"Realmente basta con recordar, para rechazarlo, que las vías pecuarias son precisamente (Ley de 27 de Junio de 1974 y Reglamento de 3 de Noviembre de 1978) bienes de dominio público, no susceptibles de prescripción y de enajenación, y que también las cuestiones sobre titularidad dominical definitiva de las mismas, ni son propias de un simple expediente de clasificación, ni en todo caso corresponde su resolución a los Tribunales de lo Contencioso-administrativo, tal y como viene siendo reiteradamente proclamado por la doctrina de esta Sala (Sentencia de 21 de marzo y 2 de Julio de 1979, Arz. 1345 y 2996; de 10 de febrero de 1989, Arz. 998; de 22 de Marzo de 1990, Arz. 5426; 10 de Junio de 1991, Arz. 4676, entre otras) en el acatamiento a lo preceptuado en la Diposición final 1 de la Ley y Reglamento."
} 
repetir lo ya expuesto en la demanda, se limita a manifestar que la cuestión susci tada por él pudo haber sido resuelta en esta Jurisdicción como cuestión prejudicial de orden civil. Pero la Sala de instancia no niega esta posibilidad, lo único que declara, con todo acierto, es que para anular el deslinde por esta causa el recu rrente hubiera debido acreditar determinados presupuestos de hecho".

En el mismo sentido hemos de destacar la Sentencia del Tribunal Superior de Justicia de Andalucía de 25 de Julio de 2003 (Arz. 225504). ${ }^{19}$

Más allá del conocimiento como una mera cuestión prejudicial, la Sentencia del Tribunal Supremo de 22 de Diciembre de 2004 (arz. 340) ha admitido con mayor amplitud la competencia de la jurisdicción contenciosa para conocer cuestiones relativas a los derechos civiles afectados por el deslinde, asî dispone expresamente en el fundamento de derecho séptimo, que cuando en el recurso contra el deslinde se aleguen derechos acreditados de forma incontrovertida y notoria (por sentencia, por transmisión efectuada por la Administración, por fe pública registral, por usucapión anterior a la clasificación) sería desviación de poder el no tener en cuenta estas alegaciones en el procedimiento de deslinde, vicio que, por tanto es controlable por la jurisdicción contencioso-administrativa:

"No obstante, para terminar, debe admitirse que por los principios de economía procesal y unidad del ordenamiento jurídico, de manera excepcional es posible invocar en vía contencioso-administrativa, como motivo de impugnación del deslinde adminis trativo, la vulneración de un derecho de propiedad que haya acreditado como absoluta mente notorio e incontrovertido en el expediente administrativo, al tiempo de identifica ción y calificación de las "ocupaciones, intrusiones, y colindancias". Cuando decimos notorio e incontrovertido,, nos estamos referiendo a que no sean precisas pruebas, valo raciones, razonamientos jurídicos, siendo pues una cuestión de constatación de hecho y no de valoración jurídica: esto será si en los casos, por ejemplo, de aportación al expe diente administrativo de una sentencia firme que haya declarado ya ese derecho de propiedad a favor del titular que realice las alegaciones, o de transmisiones efectuadas por

19 "Pues bien, centrados los términos del debate, es evidente que por estrictas razones de carácter procesal, hemos de abordar en primer lugar la falta de jurisdicción alegada por la Junta de Andalucia, toda vez que de estimarla devendría imposible conocer el resto de las cuestiones que se nos plantean, y a tal respecto, hemos de convenir con el Ministerio Fiscal en que efectivamente, del contenido de la demanda se evidencia que la cues tión planteada excede de una estricta reivindicación del derecho de propiedad, toda vez que se extiende a la causa del acto de deslinde (de carácter eminentemente administrativo), todo ello sin perjuicio de que en su ca so si fiera procedente, y siempre conforme a los términos de los arts. 4.1 y 4.2 de la LJCA se pueda resolver lo concerniente a la propiedad invocada" 
la propia Administración deslindante a favor del particular, o de constancia indubita da de la antigüedad de una usurpación (por ejemplo un edificio) de más de treinta años antes de la clasificación, o de inscripciones de las que resulte no ya la mera titularidad a favor del particular afectado, sino una adquisición con todos los requisitos del art. 34 de la LH anterior a la fecha del acto de la clasificación.

Parece lógico a juicio de la Sala y sin contravenir ni la letra ni el espiritu de la Ley vigente, que en esos casos la no consideración por la Administración deslindante de es ta alegaciones tan notoriamente bien fundadas, ha de considerarse como una desviación de poder corregible en vía Contencioso-administrativa".

Lo expuesto demuestra que la jurisprudencia ha evolucionado hacia una ampliación de la competencia del orden jurisdiccional contencioso para conocer de cuestiones relativas a derechos civiles. Se trata, como ya hemos reiterado, de un mecanismo para corregir situaciones de indefensión provocadas por la aplicación de clasificaciones en las que los propietarios colindantes no pudieron interventor ni recurrir; ahora pueden defender sus derechos al impugnar el deslinde, si bien lo deseable y procedente hubiera sido darles audiencia en el procedimiento de clasificación en lugar de obligarlos a litigar.

\section{4.b) Impugnación ante la Jurisdicción Contencioso-Administrativa}

En cuanto a la impugnación en vía administrativa y contencioso-administrativa del acto de deslinde, hemos de tener en cuenta las siguientes cuestiones:

a) Impugnación de la clasificación:

a.1) Necesidad de impugnar la clasificación para poder recurrir el contenido del acto de deslinde:

El acto administrativo de deslinde, como hemos visto, está totalmente vinculado en cuanto a su contenido por lo que se disponga en la Clasificación (art.8.1 de la Ley 3/1995 y 17 del Decreto andaluz 155/1998), de forma que el deslinde es un acto de concreción en la realidad de los terrenos de las declaraciones contenidas en la clasificación. Si de la aprobación de la clasificación que va a determinar el contenido del deslinde se advierten ya vicios de fondo sobre la existencia de vías pecuarias no suficientemente acreditada, o errores en la determinación de su anchura y trazado, y en general vicios de contenido con efectos invalidantes, es preciso impugnar el acto de la clasificación y no dejar la impugnación de esos vicios de fondo para el momento de 
la aprobación del deslinde ya que, en tal caso la respuesta de la Administración Pública, y el criterio mantenido en por los órganos jurisdiccionales, viene siendo el de rechazar la impugnación del deslinde cuando la misma se basa en los contenidos del acto de clasificación que debió ser impugnado en su momento y que considera firme e inatacable.

El criterio mantenido por tanto por la Administración y por los órganos jurisdiccionales, es pues un criterio que limita las posibilidades de impugnar el deslinde de forma que sólo puede ser recurrido autónomamente, sin necesidad de haber impugnado previamente el acto de clasificación cuando el recurso se basa en vicios formales o cuestiones procedimentales, o bien cuando lo que se alega es que el deslinde no se adecua a lo dispuesto en la clasificación. Pero no sería procedente la impugnación indirecta de la clasificación a través de la impugnación del acto de deslinde, es decir no procedería el recurso al deslinde en el que se discutiera la legalidad del contenido predeterminado por la clasificación previa.

La sentencia del Tribunal Supremo de 22 de Diciembre de 2004 (Arz. 340) es clara al respecto en su fundamento de Derecho Séptimo: "De ahi que transcurrido el plazo ordinario para recurrir el acto de clasificación, tal resolución será firme, la vía pecuaria -todavía no concretada sobre el terreno- gozará de la condición de dominio público y no podrá después impugnarse su deslinde innovando razones que tiendan a demostrar que no concurría el presupuesto histórico necesario para la clasifi cación de los terrenos como vía pecuaria"

Podemos concluir, por tanto, que en el estado actual de la jurisprudencia y la práctica administrativa la impugnación de la clasificación viene siendo por tanto la clave de que prosperen las pretensiones frente al deslinde, ya que, ni siquiera si obtenemos una sentencia favorable frente al deslinde por vicios formales o de procedimiento, podemos dar por zanjada la cuestión y por salvaguardada la integridad de "nuestra finca" si la clasificación sigue viva, pues, entonces, siendo un acto firme y consentido está siempre presente la amenaza de que la Administración inicie un nuevo expediente de deslinde con el mismo contenido plasmado en la clasificación.

No compartimos este criterio administrativo y jurisprudencial, ya que vulnera gravemente el derecho a la defensa garantizado por el art. 24 de la Constitución por los siguientes motivos:

-El deslinde es un nuevo acto administrativo, cuyo contenido, aunque coincidente con la clasificación, tiene efectos distintos; la clasificación es una 
mera declaración de existencia mientras que el deslinde tiene efectos que van a incidir sobre las titularidades inscritas en el Registro que se opongan al mismo. Por tanto no pueden limitarse a cuestiones meramente formales y procedimentales las posibilidades de defensa frente a un nuevo acto administrativo distinto de la clasificación.

-Pero es que además la situación actual que se está poniendo de manifiesto en la práctica administrativa al aplicar en los expedientes de deslinde clasificaciones de hace 50 o 60 años que se consideran firmes y consentidas a pesar de que no pudieron recurrirse, está generando un problema de auténtica denegación del derecho a la justicia.

a.2) La situación actual de los deslindes de las vías pecuarias en España: la impugnación de la aplicación de clasificaciones antiguas viciadas de nulidad y desconocidas por los propietarios colindantes afectados por los deslindes actuales

En la práctica se está produciendo una situación que podríamos calificar de orden público con los deslindes que actualmente está llevando a cabo por las Comunidades Autónomas (Andalucía, Extremadura, ...). Como ya dijimos al analizar la clasificación, las Comunidades Autónomas en general y, en concreto Andalucía, a la hora de a proceder al ejercicio de las potestades de autotutela de las vías pecuarias, están incumpliendo el orden de actuaciones que impone la Ley 3/1995 en su art. 5. En lugar de cumplir el deber de investigar que les impone el referido precepto, sin más se están remitiendo a clasificaciones que se hicieron en los años 50 y 60 por el Ministerio de Agricultura que hoy día, como ya expusimos están desfasadas -tanto por el desuso de las vías pecuarias en las que falta el uso pecuario como hecho determinante de su demanialidad tal y como se recogía en las clasificaciones, como por las usucapiones producidas al amparo de la anterior normativa-, además se trata de clasificaciones desconocidas para los propietarios afectados ya que, como expusimos, al no exigirse en las normas reguladoras de las vías pecuarias la audiencia a los propietarios colindantes, y sin tener en cuenta lo dispuesto en las normas generales de procedimiento administrativo y en la jurisprudencia, tan solo se abrió un trámite de información pública en su elaboración, y, por si fuera poco en su mayoría están plagadas de errores e inconcreciones.

La doctrina mantenida por los Tribunales Superiores de Justicia como vimos es la de que la antigüedad de estas clasificaciones no determina su inaplicación. Así se ha mantenido en sentencias como las del Tribunal Superior de Justicia de Extremadura de 20 de Junio de 2005 (arz. 173111), de 23 de Ma- 
yo de 2005 (Arz. 137669), de 23 de Mayo de 2005 (Arz. 169278), de 19 de Mayo de 2005 (Arz. 128098), de 19 de Mayo de 2005 (Arz. 128100), de 19 de Mayo de 2005 (Arz. 128107), de 23 de Mayo de 2005 (Arz. 169272), de 24 de Mayo de 2005 (Arz. 137661), de 25 de Mayo de 2005 (Arz. 137622) y el Tribunal Superior de Justicia de Andalucía ha dictado sentencia de 19 de Junio de 2000 (Arz. 76211) en el mismo sentido. Ahora bien en estas sentencias parece abrirse admitirse la posibilidad de revisar el contenido del deslinde cuando se recurre contra el mismo con independencia de si previamente se ha recurrido o no la clasificación. En ellas se hace una precisión y es que la clasificación es aplicable porque sólo el argumento de su antigüedad no determina su inaplicación, pero que otra cosa podría suceder si se alegaran otros vicios de la clasificación:

"La parte recurrente, por otra parte, no denuncia inexactitudes de aquella Orden (de Clasificación) u otros antecedentes documentales que pudieses ponerla en tela de jui cio en cuanto al trazado".

En el caso Andaluz, las Clasificaciones que vienen aplicándose por la Junta de Andalucía, en muchos casos están viciadas de nulidad por los siguientes motivos:

-Errores que determinan la imposibilidad de sus contenidos y la lesión al derecho a la igualdad (art. 62.1 c. de la Ley 30/92 y 14 de la Constitución): Se trata de clasificaciones que en su gran mayoría están plagadas de errores sobre la existencia y el trazado de las vías pecuarias de Andalucía, producidos fundamentalmente porque en aquellas clasificaciones no se tuvieron en cuenta las peculiaridades del sistema pecuario de Andalucía, sino que se trasladó sin más el sistema de la Mesta Castellana cuando las denominaciones y anchuras en Andalucía eran distintas, -Así lo ha puesto de manifiesto el Profesor Corzo en diversos informes elaborados expresamente como pericia en los recursos interpuestos contra deslindes de vías pecuarias-;

- Lesión al derecho a la defensa (Art. 62.1.a de la Ley 30/92 y 24 de la Constitución): además, estas clasificaciones hechas bajo la vigencia del Reglamento de 1944, se tramitaron, como hemos visto, sin dar audiencia a los propietarios afectados, así lo ha reconocido la propia Administración competente actualmente en diversas ocasiones, sobre la base de que la norma de 1944 no exigía expresamente esa audiencia, y olvidando que las normas de procedimiento vigentes en la época y la jurisprudencia eran claras sobre la necesidad de dar audiencia a los propietarios colindantes afectados por el deslinde.

Se omitió por tanto el trámite de audiencia a los interesados expresamente previsto actualmente en el art. 105 de la Constitución por su trascen- 
dencia en relación al derecho a la defensa y la tutela judicial efectiva garantizados por el art. 24 de la Constitución, y que en la época en que se elaboraron aquellas Clasificaciones, aunque no venía establecido en la Ley de Vías pecuarias de la época, la Ley de 19 de Octubre de 1889 que regulaba las bases del Procedimiento Administrativo a desarrollar por los distintos Ministerios si lo imponía (art. 10.2: "Instruidos y preparados los expedientes para su resolución, se comunicarán a los interesados para que dentro del plazo que se señale, y sin que pueda bajar de diez días ni exceder de treinta, aleguen y presenten los documentos y justifica ciones que consideren conducentes a sus pretensiones"), y posteriormente en la Ley de Procedimiento Administrativo de 1958 (art. 91: "Instruidos los expedientes, $e$ inmediatamente antes de redactar la propuesta de resolución, se pondrán de manifiesto a los interesados, para que en un plazo no inferior a diez días ni superior a quince, aleguen y presenten los documentos y justificaciones que estimen pertinentes") y además es abundante la jurisprudencia preconstitucional anterior a la fecha de la Clasificación que declara la trascendencia y la necesidad del trámite de audiencia por su relación al derecho a la defensa y al principio de que nadie puede ser condenado sin ser oído.

En este sentido es destacable la Sentencia del Tribunal Supremo de 27 de Marzo de 1984, que resume evolución jurisprudencial desde antes de la Constitución sobre esta materia:

"La cuestión debe ser abordada partiendo de la verdadera naturaleza del trámite de audiencia y de la motivación teleológica que constituye su razón de ser, se trata de un trámite que ha sido considerado como de observancia obligatoria -STS de 13 de Mayo de 1948-, de extraordinaria importancia -STS de 4 de Marzo de 1947-, ne cesario -STS de 25 de Abril de 1950-, más cualificado -STS de 29 de Marzo de 1943, cardinal -STS de 2 de Marzo de 1931-, sustancial-STS de 11 de Julio de 1932-, fundamental-STS de 12 de Febrero de 1951-, capital-STS de 13 de Enero de 1905-, esencial -STS de 7 de Marzo de 1950-, esencialísimo -STS de 27 de Ma yo de 1935-, sagrado -STS de 15 de Junio de 1925; es un trámite del que se puede decir todo esto porque obedece a un eterno principio de justicia, que exige que nadie pueda ser condenado sin ser oído -STS de 15 de Noviembre de 1934-, lo que justi fica que el principio se aplique en todas las jurisdicciones -SSTS de 20 de Mayo de 1903, de 23 de Abril de 1932, de 28 de Junio de 1933, de 5 de Febrero de 1947-, y que hay a formado parte de nuestro derecho histórico; llegando a alcanzar rango constitucional en nuestra ley fundamental de 27 de Diciembre de 1978"

En la mayoría de los casos, en la elaboración de las clasificaciones que ahora están sirviendo de base a los actos de deslinde tan sólo se abrió un trámite de información pública que resulta insuficiente para garantizar el dere- 
cho a la defensa, ya que este trámite es perfectamente compatible con la audiencia, y en modo alguno puede sustituirlo ${ }^{20}$.

-Se trata además de clasificaciones cuya existencia en la mayoría de los casos era insospechada por los propietarios afectados, ya que durante años las vías pecuarias han estado en desuso y no se habían traducido en deslindes y amojonamientos sobre el terreno. Son, por tanto actos que no han adquirido firmeza ya que nunca fueron notificados a los interesados.

-Por otro lado, son clasificaciones cuyo contenido hoy día ha quedado desfasado en muchos aspectos ya que recogen la existencia de vías pecuarias que ya no se usan para el tránsito ganadero por lo que la motivación o el hecho determinante de la clasificación de esas vía pecuarias ha desaparecido, y es preciso hacer una nueva clasificación en la que en su caso se clasifique la vía pecuaria como tal justificando que la misma se destina a los otros usos recogidos en la nueva Ley, que permiten mantener su existencia como tal vía pecuaria y por tanto su carácter demanial, ya que de otro modo no queda justificado en fundamento o hecho determinante del mantenimiento de su demanialidad.

En esta situación, las posibilidades que tienen los propietarios afectados para impugnar son:

Alegar estos vicios en el recurso contra el deslinde en el que, consideramos necesario para garantizar la efectividad del derecho a la defensa, que cambie el criterio jurisprudencial mantenido hasta ahora acerca de la posibilidad de impugnar los contenidos concretos del deslinde que traen causa de la clasificación, cambio de criterio que parecen haber admitido las sentencias antes referidas y que, como ya hemos visto, viene propiciado por la Sentencia del Tribunal Superior de Justicia de Andalucía de 22 de Diciembre de 2003 (Arz. 340/2004) que admite la posibilidad de alegar contra los actos de deslinde adquisiciones de los terrenos deslindados consolidadas y firmes que queden acreditadas de forma notoria e incontrovertida.

En todo caso, para el supuesto de que se inadmitiera la impugnación del contenido del deslinde sin impugnación previa de la clasificación, ante esta

${ }^{20}$ Como ha señalado la jurisprudencia (STS de 24 de Octubre de 1984, y de 4 de Junio de 1985) la finalidad de la información pública a diferencia del trámite de audiencia no reside tanto en hacer posible el derecho a la defensa sino en que se aporten datos y documentos de trascendencia para el proceso, por ello, la Administración ha de proceder necesariamente a dar audiencia a los interesados cuyos derechos resultan afectados cuando estos son conocidos. 
denegación del derecho a la defensa, las únicas vías de impugnación que quedan es plantear la revisión de oficio de las viejas clasificaciones (la nulidad nunca prescribe) conforme al art. 102 de la Ley 30/92, o bien interponer un Recuso Extraordinario de Revisión conforme al art. 118 de la Ley 30/92 sobre la base del acceso a documentos nuevos para los administrados a los que antes no podía accederse por no existir archivos y fondos documentales organizados, y por no estar suficientemente reconocido el derecho a acceder a los mismos. Estas vías de impugnación son compatibles y simultáneas con los recursos que procedan frente a los actos de deslinde, y permiten alegar los vicios de nulidad de las clasificaciones aplicadas -lesión al derecho fundamental a la defensa y al derecho a la igualdad (art. 62.1 a. De la ley 30/92) y el contenido imposible (art. 62.1.c.).

\section{b) Impugnación del acto de deslinde:}

b.1) Impugnación en vía administrativa: la Resolución aprobatoria del deslinde es susceptible de recurso de alzada en el plazo de un mes. Desestimado el recurso de alzada puede interponerse potestativamente recurso de reposición.

b.2) Impugnación en vía contencioso-administrativa: desestimado el recurso de alzada, -o de reposición en caso de que se haya interpuesto-, ya sea de forma expresa o por silencio administrativo queda expedita la vía judicial para impugnar el deslinde. El plazo para la interposición del recurso contencioso es de dos meses en el caso de que la desestimación del recurso sea expresa y, en el caso de que la desestimación del recurso lo sea por silencio administrativo no existe plazo para acudir al contencioso ${ }^{21}$.

Relevancia de la fase de prueba. Medios de prueba: En cuanto al contenido de la defensa frente al acto de deslinde, resulta esencial en la fase pro-

\footnotetext{
${ }^{21}$ El Tribunal Supremo en sentencia de 23 de Enero de 2004, y recientemente en sentencia de 4 de Abril de 2005 ha mantenido que, tras la Ley 4/1999 de reforma de la Ley 30/92 en la que el silencio administrativo negativo se concibe como una ficción jurídica y no como un verdadero acto administrativo presunto, no procede aplicar el plazo de seis meses establecido en el art. 46 de la Ley Jurisdiccional para interponer el recurso contencioso cuando lo que se impugna es un silencio negativo ya que tal limite temporal se establece sólo para el caso de impugnaciones de actos presuntos. Por tanto en el caso de recurso contencioso contra un silencio negativo no existe plazo para acudir al contencioso.
} 
batoria proponer medios de prueba que constaten la inexistencia de la vía pecuaria deslindada o, en su caso, la inexactitud de las dimensiones o el trazado recogido en el acto de deslinde, o bien que el acto de deslinde no se adecua a la clasificación. Para ello resultan esenciales pruebas documentales consistentes es documentos y cartografía histórica; si bien la interpretación de todos estos documentos requiere tener conocimientos cualificados en la materia, por lo que a fin de arrojar luz sobre su contenido y compararlo con el deslinde recurrido es esencial que los juristas y los técnicos expertos en Historia Medieval, y en el estudio de estos caminos pecuarios caminen de la mano, así es importante la práctica de una prueba pericial a fin de que un experto en la materia, a la luz de los documentos aportados pueda dictaminar sobre la existencia o no de la vía pecuaria y su configuración real y, en consecuencia sobre la corrección o no del deslinde practicado.

En el caso de los deslindes de vías pecuarias en Andalucía, la practica de estos medios de prueba ha puesto de manifiesto dos realidades esenciales: a) la excusa en la que la Administración autonómica se ha basado para remitirse sin más a clasificaciones antiguas sin tener en cuenta más documentación, ha sido precisamente la falta de documentos por tratarse de bienes que durante años han estado en desuso, por eso normalmente los parámetros empleados como guía del deslinde han sido las viejas clasificaciones y los testimonios de "los lugareños o conocedores del lugar". Con estos medios de prueba se ha constatado que la realidad es que existen otros muchos documentos que, más allá de las viejas clasificaciones de los años 50 y 60, aportan una imagen fiel y correcta de las vías pecuarias en Andalucía, y que, por tanto ha existido una clara infracción del deber de investigar; b) Por otro lado se ha constatado que estamos ante actos de clasificación y deslindes erróneos.

Las medidas cautelares: La aprobación del deslinde da pie a la recuperación de la posesión de la vía pecuaria por la Administración, y al siguiente procedimiento que es el amojonamiento que consiste en señalar físicamente sobre el terreno mediante hitos por dónde discurre la vía pecuaria, y, asimismo, legitima el desarrollo en los terrenos de la vía pecuaria de los usos propios de carácter pecuario y los compatibles y complementarios que se permiten en la regulación actual (senderismo, paseo, actividades de ocio y deportivas...). Por tanto la ejecución inmediata sobre el terreno de estas actuaciones supone necesariamente una alteración del status quo existente en el momento de la aprobación del deslinde que puede ocasionar daños de imposible o difícil reparación, sobre todo cuando las fincas por donde la vía pecuaria discurre son explotaciones agrícolas o cinegéticas, o equipamientos de ocio y deportivos como es el caso del Campo de Golf del Club Zaudín en Sevilla- que se ven al- 
teradas y cuarteadas ${ }^{22}$. Frente a este daño a los derechos de los propietarios afectados, la doctrina que vienen manteniendo los Tribunales de Justicia es que la suspensión de la ejecución del acto de deslinde no ocasiona un perjuicio al interés general, sobre todo teniendo en cuanta el tiempo que las vías pecuarias llevan inutilizadas, y además, en el caso Andaluz, los años que han transcurrido desde que se aprobaron las clasificaciones que ahora se están aplicando -aprobadas en los años 50 y 60 - sin que las vías pecuarias se hubieran deslindado con anterioridad, lo que pone de manifiesto que no existe un interés general que demande la inmediata ejecución del acto de deslinde. ${ }^{23}$

${ }^{22}$ Auto del Tribunal Supremo de 11 de Octubre de 1989 (Arz. 7354):

"Tercero.- En cambio si puede producir daños y perjuicios de difícil reparación el efecto material derivado de la atribución de la posesión al Estado de los terrenos cuestionados, porque la efectividad de esa atribución conlleva el desapoderamiento de los poseedores actuales; ese desapoderamiento puede ser inocuo si la pose sión no producía beneficio alguno al poseedor, fuera de la mera titularidad, pero puede originar perjui cios si en los terrenos cuestionados se realizan actividades productivas que han de venir al traste con el cam bio del poseedor. En este segundo aspecto sólo el estudio de las circunstancias del caso concreto nos dará la solución adecuada.

Cuarto.- En el supuesto que nos ocupa, los terrenos que el deslinde atribuye al Estado están destinados a una explotación agrícola, y, en consecuencia, la efectividad del cambio del poseedor perjudicaría al en tramado económico y humano en que la explotación consiste; se trata, por lo tanto, de un caso en que pro cede claramente la suspensión, a tenor de lo dispuesto en el art. 122.2 de la Ley Jurisdiccional, y acertó por tanto la Audiencia Nacional al concederla en cuanto a este extremo".

Asimismo resulta ilustrativa de la Sentencia del Tribunal Supremo de 13 de Diciembre de 1993 (Arz. 1755/1993) que establece:

"Esta Sala que ahora enjuicia ya ha tenido la ocasión de pronunciarse en la Sentencia de fecha de 13 de Noviembre de 1993, dictada en el Recurso de Casación 2302/1993, en un supuesto semejante al actual. Así el Auto recurrido -al igual que en aquélla-, se distingue entre el deslinde y sus inmediatas consecuencias jurí dicas, y la material imposibilidad de continuar los recurrentes, mientras se decide definitivamente la confor midad a derecho de los actos administrativos impugnados en el asunto principal del que la pieza de suspen sión dimana, lo que les ha de privar de la explotación agrícola de los terrenos sobre los que el deslinde en cuestión se contrae. La declaración jurídica del deslinde no ha de causar daños o perjuicios de imposible o di fícil reparación, pero no ocurre otro tanto con la privación inmediata, sin esperar el resultado del Recur so Contencioso-Administrativo principal, de la explotación agrícola de los terrenos en cuestión, caso que des pués prospere en vía jurisdiccional la impugnación de los actos recurridos; ya que, los daños y perjuicios que ello ocasionaría a los demandantes, por la propia naturaleza de la explotación agrícola serían, cuan to menos, de muy difícil reparación, por la evidente cuantificación, derivada de aleatoriedad de la conse cución de productos derivados de aquella". 


\section{c) Efectos de la anulación o declaración de nulidad del acto de deslinde sobre el Planeamiento Urbanístico y de Ordenación del Territorio}

La anulación o declaración de nulidad del acto de deslinde tiene un efecto dominó sobre otros actos y normas posteriores. En efecto los planes de urbanismo y de ordenación del territorio han de recoger y plasmar el contenido de los actos de deslinde de vías pecuarias, clasificándolos como suelo no urbanizable de especial protección (art. 39.1 del decreto 155/1998). Declarado nulo el acto por el que deslinda una vía pecuaria, ello determina asimismo la nulidad del contenido del planeamiento urbanístico y de ordenación del territorio en cuanto a la vía pecuaria cuyo trazado recoge, lo que impone que los órganos competentes procedan a la adaptación de los planes urbanísticos y de ordenación del territorio. Se trata de una relación acto-reglamento sin duda curiosa, ya que es el plan o norma reglamentaria el que aparece vinculado por el acto y no al contrario.

\footnotetext{
${ }^{23}$ A título de ejemplo podemos citar, entre otros el Auto de la Sala de lo Contencioso de Sevilla, Sección Tercera, de 12 de Marzo de 2001 (recurso contencioso 921/2000):

"A virtud de lo dispuesto en los arts. 130.1 y 2 de la Ley 29/1998 de 13 de Julio, valorando los intereses en conflicto, se ha de indicar que el perjuicio que para el interés público supone la suspensión del acto impug nado, como se alega por el recurrente, en verdad no consta, por el período en que lleva inutilizada la supues ta y controvertida cañada, tampoco que la suspensión del acto impugnado añada un plus de desprotección a su existencia o impida, o al menos dificulte el normal funcionamiento de la labor de policía de la Adminis tración sobre el dominio público hasta que recaiga sentencia definitiva mediante la siempre posible restitución a su estado primitivo, cuya ejecución, ahora, por el contrario mediante la alteración de ese status quo, sí pue de ocasionar perjuicios de imposible o dificil reparación"
}

En el mismo sentido el auto de la misma fecha, 12 de Marzo de 2001 de la sala de Sevilla pero la sección primera (recurso contencioso 930/00) establece:

"En el caso de autos la Clasificación de las Vias Pecuarias fue efectuada en 1957, no procediéndose el des linde hasta el año 1998, de donde se desprende que las exigencias de ejecución que el interés público presenta son tenues, por lo que es evidente que el deslinde, en cuanto supone una desposesión de la actora de una parte de la finca de la que vienen disfrutando, causa unos perjuicios que justifican la suspensión del acto recurrido. Debemos por tanto estimar el recurso de súplica y acordar la suspensión del acto recurrido".

Asimismo, el auto de la Sala de lo Contencioso de sevilla, Sección Primera de 22 de Enero de 2001 (recurso contencioso 929/00) dispuso que la suspensión del deslinde "no afecta gravemente al interés general porque el desuso de las cañadas es notorio y unos años más de espera no impiden el fin pretendido, por el contrario la ejecución material del deslinde con la recuperación de la posesión de los terrenos en cuestión haría perder en parte la finalidad legítima del recurso al privar a la actora de unos terrenos afectos a su explotación". 
En caso de no procederse a la adaptación de oficio por la Administración competente, conforme a lo dispuesto en el art. 32.1.1 ${ }^{\circ}$ a) de la LOUA puede formularse a instancia de parte propuesta para que se proceda a la modificación del planeamiento general urbanístico, y asimismo, cabría la posibilidad de plantear una revisión de oficio del planeamiento urbanístico o de ordenación del territorio en cuanto al contenido relativo a la vía pecuaria (art. 102 de la Ley $30 / 92)^{24}$.

\footnotetext{
${ }^{24}$ Se trata de una vía que entendemos posible aun cuando no puede desconocerse que algún sector doctrinal y sobre todo voces de la propia Administración han puesto en duda el que, conforme al art. 102 de la Ley 30/92 la revisión de oficio de los reglamentos nulos pueda iniciarse a instancia de parte.
} 